\title{
17. BIOSTRATIGRAPHIC AND PALEOENVIRONMENTAL INTERPRETATION OF THE GOBAN SPUR REGION BASED ON A STUDY OF CALCAREOUS NANNOPLANKTON1
}

\author{
Carla Müller, Geologisch-Paläontologisches Institut der Universität, Frankfurt ${ }^{2}$
}

\begin{abstract}
The nannoplankton stratigraphy of Leg 80 (Goban Spur and adjacent Porcupine Abyssal Plain) is summarized. Oldest sediments overlying Hercynian basement are lower to middle Barremian (Site 549). On the ocean crust (Site 550) the oldest strata are upper Albian. The Barremian syn-rift sediments are separated from the post-rift sediments (Albian) by an unconformity representing a 12 m.y. hiatus.

Black shales rich in organic matter were deposited around the Cenomanian/Turonian boundary. Sediments of similar age and lithology have a wide distribution in the North Atlantic and in northern Europe. Deposition of these sediments coincided with volcanic activity.

The Turonian to Maestrichtian sequences are condensed in comparison with the thick Albian and Cenomanian deposits. This may be linked to high sea-level stand and trapping of sediments on the shelf.

Thick Maestrichtian sections were encountered at Sites 550 and 551, where interbeds of turbidites are characteristic. The Cretaceous/Tertiary boundary appears to have been relatively undisturbed where it was drilled at Site 550 .

The Tertiary sections are interrupted by several unconformities, which can be correlated with global unconformities described by Vail and Hardenbol (1979). The Eocene/Oligocene boundary was recovered at Sites 548 and 549.

The distribution of nannoplankton assemblages makes it possible to reconstruct a curve of relative surface-water temperature for the Tertiary. Latitudinal differentiation of the assemblages has become more pronounced since the Oligocene, and particularly since the middle Miocene.

The beginning of the glaciation in the northern hemisphere about 2.7 to $2.5 \mathrm{~m}$.y. ago is indicated by the disappearance of discoasters and the occurrence of ice-rafted material. The Quaternary sequences are characterized by alternations of nannoplankton-rich (interglacial) and nannoplankton-poor (glacial) layers.
\end{abstract}

\section{INTRODUCTION}

During DSDP-IPOD Leg 80 (Goban Spur), four sites (548-551) were drilled on a transect from the upper continental slope to the abyssal plain (Fig. 1).

Nannoplankton age determinations for the Cretaceous strata are based mainly on the zonations of Thierstein (1973, 1976), but some zones described by Martini (1976), Cepek and Hay (1969), and Bukry and Bramlette (1970) have also been integrated. The "standard zonation" of Martini (1971) is used for the Tertiary. Determination of these zones is possible without difficulty in the Paleogene and lower Neogene, which recorded more uniform climates and little latitudinal differentiation of nannoplankton assemblages. The zonal boundaries younger than the middle Miocene are more difficult to determine precisely, owing to the scarcity or absence of index fossils, caused by decreasing water temperature. This is especially true for the Pliocene, so only a rough subdivision of this interval can be given.

The biostratigraphic and paleoenvironmental interpretations given in this report are based on investigation of about 1550 samples from four sites (Figure 1). Table 1 summarizes the biostratigraphic results. The distribution of species and their abundance and state of preservation are given in the range charts (Tables 2-12). Only selected samples are listed. Further detailed biostrati-

\footnotetext{
${ }^{1}$ Graciansky, P. C. de, Poag, C. W., et al., Init. Repts. DSDP, 80: Washington (U.S. Govt, Printing Office). Germany.
}

graphic discussions may be found in the site chapters of this volume and in Müller (1979a).

\section{BIOSTRATIGRAPHY AND PALEOENVIRONMENTS}

\section{Lower Cretaceous}

\section{Barremian}

The oldest sedimentary rocks, overlying slightly metamorphosed sandstone of the Hercynian basement (of middle to late Devonian age), are of middle to early Barremian, and perhaps late Hauterivian age (Site 549). They are a sequence of syn-rift sediments separated from the post-rift sediments by an unconformity representing the late Barremian, most of the Aptian, and the greatest part of the early Albian (about $12 \mathrm{~m}$.y.). The lower part of the Barremian sequence is barren of nannoplankton (Cores 549-83 to 549-93). The sediments are rich in detrital material and fine-grained pyrite, and in some layers plant fragments are common. The sediments were deposited in a shallow environment near the continent under restricted conditions. They are characterized by the dominance of arenaceous foraminifers (Magniez and Sigal, this vol.).

Within the interval from Core 549-70 to Core 549-82 (795.0-879.0 m sub-bottom), nannofossils are rare, and occur only in scattered layers. They are small, and the assemblages are of low diversity, containing Conusphaera mexicana, Nannoconus colomi, Parhabdolithus splendens, Reinhardtites fenestrata, Watznaueria barnesae, W. communis, Stephanolithion laffittei, and Cretarhab- 


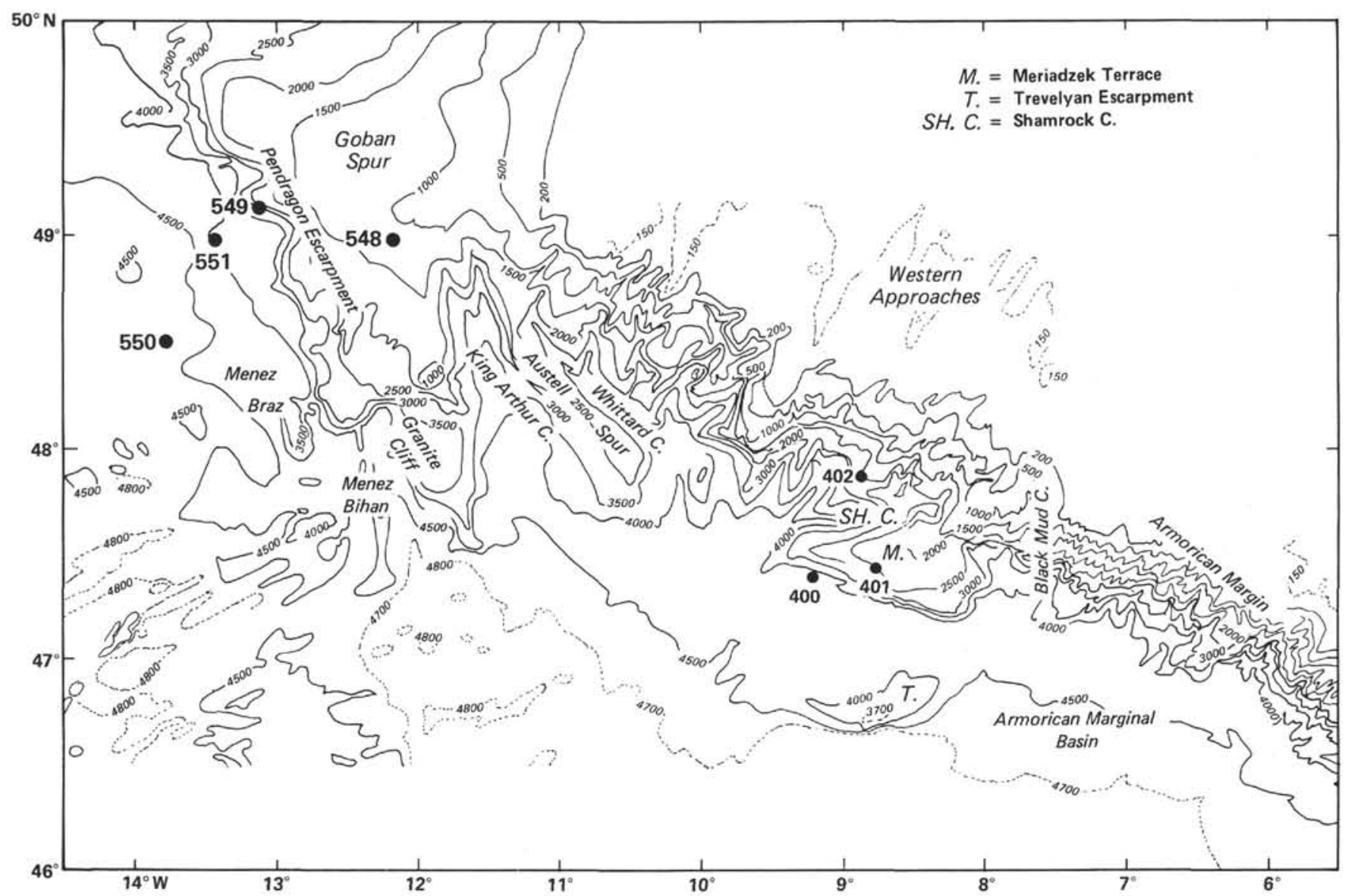

Figure 1. Bathymetry (meters), major topographic features, and IPOD site locations in the northern Biscay region (after Montadert et al., 1979).

dus angustiforatus. The scarcity of the nannoplankton within these horizons is probably a result of dilution by the large amount of terrigenous material. Pyrite and plant fragments are common in several layers. These sediments also were deposited in a shallow environment, but with increasing marine influence.

There was almost no recovery from 755 to $795 \mathrm{~m}$ subbottom (Cores 549-62 to 549-69). The few fragments from this interval are limestones, together with pieces of brachiopods, corals, bryozoans, and echinoid spines. These sediments were deposited in an inner shelf environment (Rat et al., this vol.).

The deposits from Core 549-53 to Core 549-60 (673.0$746.0 \mathrm{~m}$ sub-bottom) accumulated under open marine conditions in an outer-shelf to upper-slope environment, as shown by the abundance of Nannoconus colomi and Micrantholithus obtusus, which are typical forms of a relatively shallow, near-shore environment. Nannoplankton are generally common. In some horizons, however, the nannofossils occur in low abundance and are of small size, whereas the amount of fine-grained material is greater. This indicates fluctuations in transport from the continent. The nannoplankton assemblages are of high diversity. Nannoconus colomi occurs in varying abundance, but is generally rare within the horizons rich in detrital material.

Sediments from the upper part of Core 549-53 are red (hematite), probably as a result of subaerial alteration.
The nannofossils within this level are poorly preserved (broken and etched). The Barremian at Site 549 is overlain by a few meters of sandy dolosparite of unknown age, which may be a remnant of Aptian deposition.

\section{Aptian-Albian}

Definite Aptian sediments were not encountered at the Leg 80 drill sites. This is quite different from Sites 400 to 402 , drilled in the Bay of Biscay (Leg 48), where thick Aptian sequences were recovered. A thick Aptian sequence appears to be present, however, northeast of Site 549 , as determined from seismic-sequence analysis (see Site 549 chapter, this vol.).

Probably the uppermost part of the lower Albian ( $\mathrm{Pa}$ rhabdulus angustus Zone) overlies the sandy dolosparite at Site 549 (top of Core 549-52). Nannoplankton are common but strongly broken, and mainly dissolutionresistant species are present. The abundance of nannoplankton indicates subsidence of Site 549 to relatively deep-water conditions. This conclusion is supported by the rare occurrence of Nannoconus minutus in the absence of other species of Nannoconus.

A thick middle Albian sequence (Prediscosphaera cretacea Zone), $180.0 \mathrm{~m}$ thick, is present at Site 549 . It is characterized by an alternation of light gray carbonaterich layers (about $83 \% \mathrm{CaCO}_{3}$ ) and dark layers poor in carbonate (as little as $15 \% \mathrm{CaCO}_{3}$ ) that contain a higher proportion of detrital material and plant fragments. 
Table 1. Nannoplankton stratigraphy of holes drilled on Leg $80 .^{\mathrm{a}}$

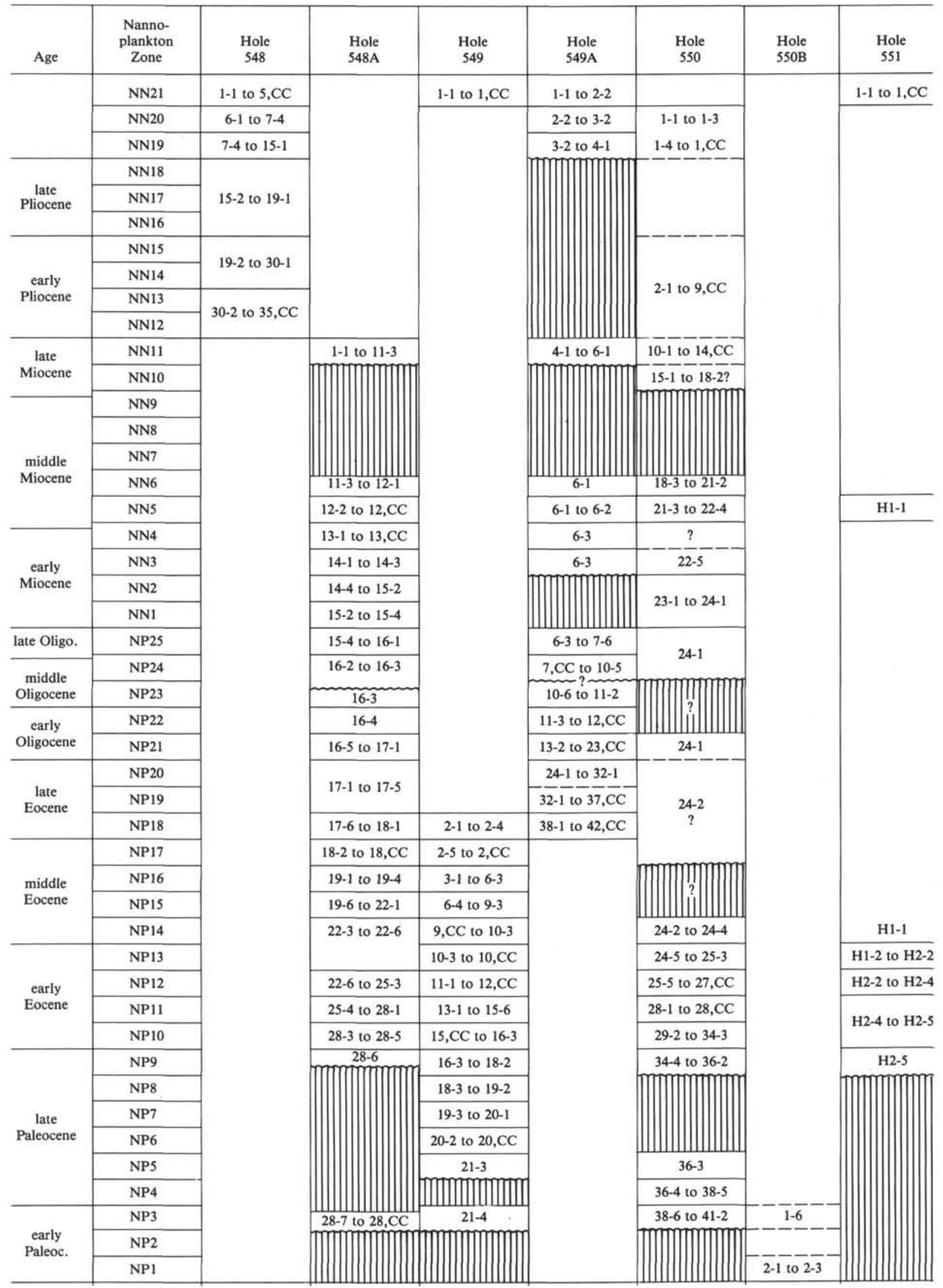


Table 1. (Continued).

\begin{tabular}{|c|c|c|c|c|c|c|c|c|}
\hline Age & $\begin{array}{l}\text { Nanno- } \\
\text { plankton } \\
\text { Zone }\end{array}$ & $\begin{array}{c}\text { Hole } \\
548\end{array}$ & $\begin{array}{l}\text { Hole } \\
548 \mathrm{~A}\end{array}$ & $\begin{array}{l}\text { Hole } \\
549\end{array}$ & $\begin{array}{l}\text { Hole } \\
549 \mathrm{~A}\end{array}$ & $\begin{array}{l}\text { Hole } \\
550\end{array}$ & $\begin{array}{l}\text { Hole } \\
550 \mathrm{~B}\end{array}$ & $\begin{array}{c}\text { Hole } \\
551\end{array}$ \\
\hline \multirow{2}{*}{$\begin{array}{l}\text { Maestrich- } \\
\text { tian }\end{array}$} & M. mura & & $29-1$ to $30, \mathrm{CC}$ & $21-4$ to $22-1$ & & $41-2$ to $43-2$ & $2-3$ to $7-1$ & \\
\hline & L. quadratus & & $31-1$ to $33-1$ & & & $43-3$ to $47-1$ & $7-2$ to $8-2$ & \\
\hline \multirow{2}{*}{$\begin{array}{c}\text { late } \\
\text { Campanian }\end{array}$} & \multirow{2}{*}{ T. trifidus } & & $33-3$ to $34, \mathrm{CC}$ & $22-2$ to $23-2$ & & $47-2$ to $47, \mathrm{CC}$ & $8-2$ to $13-3$ & $2-1$ to $3, \mathrm{CC}$ \\
\hline & & & $35-1$ to $35, \mathrm{CC}$ & |||||||||||||| $\mid$ & & & \multirow[b]{2}{*}{$\begin{array}{c}13-3 \text { to } 14-3 \\
?\end{array}$} & $4-1$ to $4, \mathrm{CC}$ \\
\hline $\begin{array}{c}\text { early } \\
\text { Campanian }\end{array}$ & B. parca & & & $23-4$ to $23, \mathrm{CC}$ & & & & \\
\hline $\begin{array}{l}\text { Santonian- } \\
\text { Coniacian }\end{array}$ & M. furcatus & & & $24-1$ to $25, \mathrm{CC}$ & & & $\begin{array}{l}14-3 \text { to } 15-1 \\
15-1 \text { to } 15-3\end{array}$ & \\
\hline Turonian & C. exiguum & & & $26-1$ to $27 ?$ & & & II ? & $5-1$ to $5, \mathrm{CC}$ \\
\hline Cenoman. & L. alatus & & & \multirow{2}{*}{$28-1$ to $30, \mathrm{CC}$} & & & & 6-1 to 6-3 \\
\hline \multirow{2}{*}{ Albian } & E. turriseiffeli & & & & & & \multirow{2}{*}{$15-4$ to $25-4$} & \\
\hline & P. cretacea & & & $31-1$ to $50, \mathrm{CC}$ & & & & \\
\hline $\begin{array}{c}\text { late } \\
\text { Aptian }\end{array}$ & P. angustus & & & $52-1 ?$ & & & & \\
\hline $\begin{array}{l}\text { early } \\
\text { Aptian }\end{array}$ & C. litterarius & & & & & & & \\
\hline \multirow{2}{*}{ Barremian } & M. hoschulzi & & & & & & & \\
\hline & L. bollii & & & $53-1$ to 93 & & & & \\
\hline
\end{tabular}

The light layers are rich in sparite, and, in several layers, sponge spicules. Nannoplankton are rare within these sediments, probably because of recrystallization. The dark layers are rich in well-preserved, dissolution-resistant species, whereas the more fragile ones are broken and etched. Fine-grained detrital material, pyrite, and plant fragments are common. This cyclic sedimentation probably can be explained by climatic fluctuations and varying input of terrigenous material (Mélières, 1979; de Boer and Wonders, 1981), and by changing productivity. Comparable sediments were encountered in the Albian at Sites 400 and $402(\operatorname{Leg} 48)$.

\section{Upper Cretaceous}

\section{Cenomanian}

An unconformity representing the upper Albian and perhaps the lowermost Cenomanian probably exists at Site 549 , as indicated by a distinct lithologic change recognized within Core 549-31 by downhole geophysical measurements. This unconformity is well known from other sites in the North Atlantic (de Graciansky et al., 1982), and may correspond to a global unconformity within the lower Cenomanian (Vail et al., 1977). The content of nannofossils in the Cenomanian sediments at Site 549 has been diminished by recrystallization resulting from strong diagenesis (formation of biogenic opal-CT by dissolution of siliceous microfossils). Cenomanian strata are identified by the presence of Lithraphidites alatus, the first-occurrence datum of which is at the base of the Cenomanian. In the material from Leg 80, however, L. alatus occurs somewhat higher within the Cenomanian section. It never becomes frequent.

\section{Turonian}

A very distinct layer of "black shale" rich in organic matter $(8-11 \%)$ characterizes the Cenomanian/Turonian boundary (Sites 549 and 551). This layer has been observed also at other sites drilled in the North Atlantic (de Graciansky et al., 1982), and its occurrence in northwestern Europe has been described (Hart and Bigg, 1981). The corresponding anoxic event coincided with a period 
Table 2. Distribution of nannofossils in Pliocene to Pleistocene sediments, Hole 548. Abundance (visual estimates): $\mathrm{A}=$ abundant, $\mathrm{C}=$ common, $\mathrm{F}=$ few, $\mathrm{R}=$ rare; preservation: $\mathrm{G}=$ good, $\mathrm{M}=$ moderate, $\mathrm{P}=$ poor; $\mathrm{X}=$ reworking. Wavy line denotes unconformity; less certain unconformities are shown in left two columns only.

\begin{tabular}{|c|c|c|c|c|c|c|c|c|c|c|c|c|c|c|c|c|c|c|c|c|c|}
\hline Age & Zone & $\begin{array}{c}\text { Sample } \\
\text { (interval in } \mathrm{cm} \text { ) }\end{array}$ & 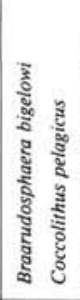 & 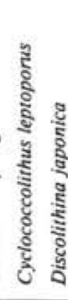 & 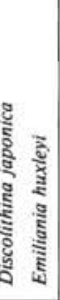 & 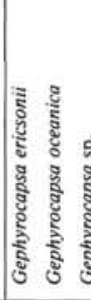 & 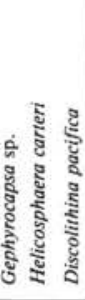 & 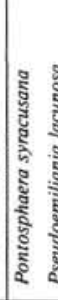 & 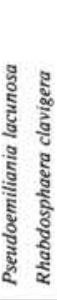 & 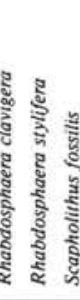 & 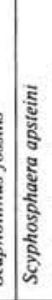 & 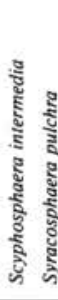 & 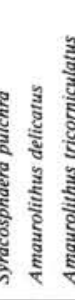 & & 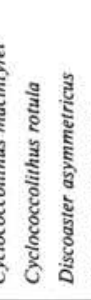 & 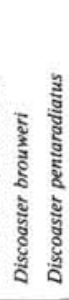 & & 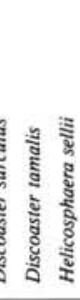 & 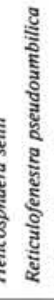 & 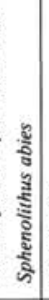 & 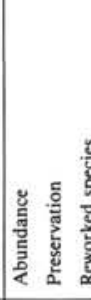 \\
\hline \multirow[t]{2}{*}{$\begin{array}{c}\text { late } \\
\text { Pleistocene }\end{array}$} & $\mathrm{NN} 21$ & $\begin{array}{l}1-1, \text { top } \\
1-1,14-17 \\
1-2,90-93 \\
1-3,20-23 \\
2-1,20-23 \\
2-2,20-23 \\
2-3,49-50 \\
2-4,33-36 \\
2-5,33-36 \\
2-6,33-36 \\
2-7,33-36 \\
3-1,30-31 \\
3-1,76-79 \\
3-2,20-21 \\
3-3,76-79 \\
3-4,76-78 \\
3-5,76-79 \\
3, C C \\
4-2,61-65 \\
4-4,61-65 \\
4-6,20-23 \\
5-1,64-67 \\
5-3,21-24 \\
5-5,21-24 \\
5, C C\end{array}$ & $\begin{array}{l}\text { C } \\
\text { A } \\
\\
\text { F } \\
\text { R } \\
\text { R } \\
\text { C } \\
\text { A } \\
\text { C } \\
\text { R } \\
\text { C } \\
\text { F } \\
\text { C } \\
\text { F } \\
\text { C } \\
\text { C } \\
\text { F } \\
\text { C } \\
\text { C } \\
\text { R } \\
\text { C }\end{array}$ & $\begin{array}{l}\text { F } \\
C \\
\text { R } \\
\text { R } \\
\text { F } \\
\text { F } \\
\text { F } \\
\text { F } \\
F \\
F \\
F \\
\text { C } \\
F \\
F \\
F \\
F \quad R \\
\end{array}$ & $\begin{array}{ll}\mathrm{A} \\
\mathrm{A} \\
\mathrm{F} \\
\mathrm{F} \\
\mathrm{F} \\
\mathrm{F} \\
\mathrm{C} \\
\mathrm{A} \\
\mathrm{A} \\
\mathrm{A} \\
\mathrm{C} \\
\mathrm{C} \\
\mathrm{C} \\
\mathrm{C} \\
\mathrm{C} \\
\mathrm{F} \\
\mathrm{C} \\
\mathrm{F} \\
\mathrm{F} \\
\mathrm{F} \\
\mathrm{F} \\
\mathrm{F} \\
\mathrm{R} & \mathrm{C} \\
\mathrm{C} & \end{array}$ & $\begin{array}{ll}A \\
A \\
A & R \\
F \\
F \\
F \\
F \\
F \\
F \\
C \\
C \\
C \\
C \\
C \\
F \\
C \\
C \\
C \\
C \\
C \\
F \\
C \\
C \\
\text { C } \\
C \\
C \\
A \\
F \\
C \\
C \\
C\end{array}$ & $\begin{array}{l}\mathrm{F} \\
\mathrm{R} \\
\mathrm{F} \\
\mathrm{F} \\
\mathrm{F} \\
\mathrm{F} \\
\mathrm{F} \\
\mathrm{F} \\
\mathrm{R} \\
\mathrm{R} \\
\\
\mathrm{F}\end{array}$ & $\begin{array}{l}\mathrm{R} \\
\mathrm{R} \\
\mathrm{R} \\
\\
\\
\end{array}$ & $R \quad R$ & $\begin{array}{lll}\mathrm{R} & \mathrm{F} & \\
\mathrm{F} & \mathrm{R}\end{array}$ & $\begin{array}{l}R \\
R\end{array}$ & $\begin{array}{ll} & R \\
& F \\
& R \\
& F \\
R & F\end{array}$ & $\begin{array}{l}\text { R } \\
\text { F } \\
\text { R } \\
F\end{array}$ & & & & & & & & $\begin{array}{lll}A & G & X \\
A & G & X \\
R & G & X \\
R & G & X \\
R & G & X \\
F & G & X \\
R & G & X \\
C & G & X \\
C & G & X \\
C & G & X \\
A & G & X \\
C & G & X \\
A & G & X \\
F & G & X \\
C & G & X \\
C & G & X \\
R & G & X \\
C & G & X \\
A & G & X \\
R & G & X \\
C & G & X \\
A & G & X \\
R & G & X \\
C & G & X \\
F & G & X\end{array}$ \\
\hline & $\mathrm{NN} 20$ & $\begin{array}{l}6-1,50-51 \\
6-3,16-19 \\
6-5,16-19 \\
6, C C \\
7-2,40-43\end{array}$ & $\begin{array}{l}\mathrm{C} \\
\mathrm{A} \\
\mathrm{F} \\
\mathrm{F} \\
\mathrm{F}\end{array}$ & $\begin{array}{ll}\mathrm{F} & \mathrm{R} \\
\mathrm{F} & \\
\mathrm{F} & \\
\mathrm{F} & \end{array}$ & & \begin{tabular}{|l}
$\mathrm{A}$ \\
$\mathrm{A}$ \\
$\mathrm{F}$ \\
$\mathrm{F}$ \\
$\mathrm{A}$
\end{tabular} & $\begin{array}{l}\mathrm{F} \\
\mathrm{F} \\
\mathrm{F}\end{array}$ & & & R & & $\stackrel{F}{F}$ & $\begin{array}{l}F \\
F\end{array}$ & & & & & & & & $\begin{array}{lll}A & G & X \\
A & G & X \\
R & G & X \\
R & G & X \\
R & G & X \\
\end{array}$ \\
\hline $\begin{array}{c}\text { early } \\
\text { Pleistocene }\end{array}$ & NN19 & $\begin{array}{l}7-4,40-43 \\
7-6,103-104 \\
8-1,69-70 \\
8-3,69-70 \\
89-5,69-70 \\
9-1,20-23 \\
9-3,20-23 \\
10-1,121-122 \\
10-3,117-119 \\
10-5,120-192 \\
11-2,50-53 \\
11-4,50-53 \\
11, \mathrm{CC} \\
12, \mathrm{CC} \\
13-3,35-38 \\
13, \mathrm{CC} \\
14, \mathrm{CC} \\
\end{array}$ & $\begin{array}{l}\text { A } \\
\text { A } \\
\text { A } \\
\text { A } \\
\text { C } \\
\text { C } \\
\text { C } \\
\text { C } \\
\text { C } \\
\text { F } \\
\text { C } \\
\text { C } \\
\text { C } \\
\text { C } \\
\text { C }\end{array}$ & $\begin{array}{ll}\mathrm{F} \\
\mathrm{F} \\
\mathrm{F} \\
\mathrm{C} & \mathrm{R} \\
\mathrm{C} & \mathrm{R} \\
\mathrm{C} & \\
\mathrm{C} & \\
\mathrm{C} & \mathrm{F} \\
\mathrm{F} & \mathrm{R} \\
\mathrm{C} & \\
\mathrm{C} & \mathrm{F} \\
\mathrm{C} & \\
\mathrm{F} & \mathrm{F} \\
\mathrm{F} & \mathrm{F} \\
\mathrm{C} & \mathrm{C}\end{array}$ & $\begin{array}{l}\text { R } \\
\text { F } \\
\text { R } \\
\text { F } \\
\text { F } \\
\text { F } \\
C\end{array}$ & 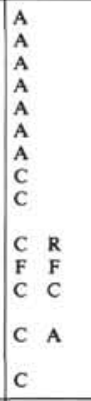 & $\begin{array}{l}\mathrm{F} \\
\mathrm{F} \\
\mathrm{F} \\
\mathrm{F} \\
\mathrm{F} \\
\mathrm{F} \\
\mathrm{F} \\
\mathrm{F} \\
\mathrm{F} \\
\\
\mathrm{C}\end{array}$ & & $\begin{array}{ll}\mathrm{F} & \\
\mathrm{F} & \\
\mathrm{F} & \mathrm{R} \\
\mathrm{F} & \\
\mathrm{F} & \\
\mathrm{F} & \mathrm{R} \\
\mathrm{F} & \\
\mathrm{F} & \\
\mathrm{C} & \mathrm{R} \\
\mathrm{C} & \\
\mathrm{F} & \\
\mathrm{F} & \\
\mathrm{F} & \\
\mathrm{F} & \\
\mathrm{F} & \\
\mathrm{F} & \\
\end{array}$ & 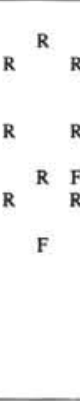 & & $\begin{array}{l}\mathrm{F} \\
\mathrm{F} \\
\mathrm{F} \\
\mathrm{F} \\
\mathrm{F} \\
\mathrm{F} \\
\mathrm{F} \\
\\
\mathrm{F} \\
\mathrm{F} \\
\mathrm{C}\end{array}$ & $\begin{array}{l}F \\
F \\
F \\
F \\
F \\
F \\
F \\
F \\
F \\
F\end{array}$ & & & & & & & & 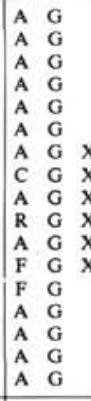 \\
\hline $\begin{array}{c}\text { late } \\
\text { Pliocene }\end{array}$ & $\begin{array}{l}\text { NN18- } \\
\text { NN16 }\end{array}$ & $\begin{array}{l}15-2,30-32 \\
15-6,30-33 \\
16-3,20-23 \\
17, C C \\
18-3,42-45 \\
19-1,45-48\end{array}$ & $\begin{array}{l}\text { F } \\
\text { C } \\
\text { C } \\
\text { A } \\
\text { A } \\
\text { C }\end{array}$ & $\mathbf{F}$ & & R & $\begin{array}{l}\mathrm{F} \\
\mathrm{F} \\
\mathrm{F} \\
\mathrm{F} \\
\mathrm{F}\end{array}$ & & $\begin{array}{ll}\mathbf{F} & \mathbf{R} \\
\mathbf{F} & \\
\mathbf{C} & \\
\mathrm{C} & \end{array}$ & $\begin{array}{rl} & F \\
R & F \\
& F\end{array}$ & & $\begin{array}{l}\mathrm{C} \\
\mathrm{F} \\
\mathrm{F} \\
\mathrm{F} \\
\mathrm{F} \\
\mathrm{F}\end{array}$ & $\begin{array}{l}C \\
F \\
F \\
F \\
F\end{array}$ & $\begin{array}{l}\text { C } \\
\text { C } \\
\text { C } \\
\text { R } \\
\text { C } \\
\text { F }\end{array}$ & $\begin{array}{l}c \\
c \\
c \\
c \\
c \\
F\end{array}$ & $R$ & & & & & $\begin{array}{lll}\mathrm{A} & \mathrm{G} & \mathrm{X} \\
\mathrm{A} & \mathrm{G} \\
\mathrm{C} & \mathrm{G} \\
\mathrm{C} & \mathrm{G} \\
\mathrm{A} & \mathrm{G} \\
\mathrm{C} & \mathrm{G} \\
\end{array}$ \\
\hline $\begin{array}{c}\text { early } \\
\text { Pliocene }\end{array}$ & $\begin{array}{l}\text { NN15- } \\
\text { NN12 }\end{array}$ & $\begin{array}{l}19-2,45-48 \\
20-1,10-13 \\
21-4,80-83 \\
22-2,102-103 \\
23-1,108-110 \\
24-3,57-60 \\
25, \mathrm{CC} \\
26-2,79-80 \\
27-2,32-35 \\
28-3,10-13 \\
29-2,60-63 \\
30-1,60-63 \\
31-1,60-63 \\
32-1,60-63 \\
33-2,60-63 \\
34-1,60-63 \\
34, \mathrm{CC} \\
35, \mathrm{CC}\end{array}$ & $\begin{array}{l}\text { c } \\
\text { C } \\
\text { c } \\
\text { C } \\
\text { c } \\
\text { c } \\
\text { C } \\
\text { c } \\
\text { c } \\
\text { C } \\
\text { C } \\
\text { C } \\
\text { C } \\
\text { c } \\
\text { C } \\
\text { c } \\
\text { C } \\
\text { c }\end{array}$ & F & & & $\begin{array}{l}\mathrm{F} \\
\mathrm{F} \\
\mathrm{F} \\
\mathrm{F} \\
\mathrm{F} \\
\mathrm{F} \\
\mathrm{F} \\
\mathrm{F} \\
\mathrm{F} \\
\mathrm{F} \\
\mathrm{F} \\
\mathrm{F} \\
\mathrm{F} \\
\mathrm{F} \\
\mathrm{F} \\
\mathrm{F} \\
\mathrm{F} \\
\mathrm{F}\end{array}$ & & $\begin{array}{l}\text { C } \\
C \\
C \\
C \\
\\
F \\
F \\
F \\
F \\
F\end{array}$ & $\begin{array}{ll}\mathrm{F} & \\
\mathrm{F} & \mathrm{R} \\
\mathrm{R} & \mathrm{R}\end{array}$ & & $\begin{array}{l}\mathrm{F} \\
\mathrm{C} \\
\mathrm{F} \\
\mathrm{F} \\
\mathrm{C} \\
\mathrm{C} \\
\mathrm{C} \\
\mathrm{F} \\
\mathrm{F} \\
\mathrm{F} \\
\mathrm{F} \\
\mathrm{F}\end{array}$ & $\begin{array}{ll}F & \\
C & \\
F & \\
C & \\
C & \\
C & \\
F & \\
F & \\
F & \\
F & \\
F & \\
& R \\
& \\
& F\end{array}$ & $\begin{array}{l}\text { C } \\
\text { C } \\
\text { F } \\
\text { C } \\
\text { C } \\
\text { F } \\
\text { F } \\
\text { C } \\
\text { C } \\
\text { C } \\
\text { C } \\
\text { C } \\
\text { C } \\
\text { C } \\
\text { C } \\
\text { C } \\
\text { C } \\
\text { C }\end{array}$ & $\begin{array}{lll}c & \\
c & \\
F & \\
c & \\
c & \\
F & \\
F & \\
c & R \\
c & \\
c & \\
c & \\
c & R \\
c & R \\
c & \\
c & \\
c & \\
c & \\
c & & \\
c & \end{array}$ & 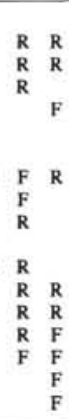 & $\begin{array}{ll}R \\
R \\
R \\
F \\
F \\
C \\
F \\
R \\
R \\
R \\
R \\
R \\
R \\
F \\
F \\
F\end{array}$ & $\begin{array}{ll} & \mathrm{C} \\
& \mathrm{F} \\
& \mathrm{F} \\
\mathrm{C} \\
\mathrm{F} \\
\mathrm{F} & \mathrm{F} \\
\mathrm{F} & \mathrm{F} \\
\mathrm{F} & \\
\mathrm{F} & \mathrm{F} \\
\mathrm{F} & \\
\mathrm{F} & \end{array}$ & $\begin{array}{ll}\mathrm{C} & \mathrm{F} \\
\mathrm{F} & \\
& \mathrm{F} \\
\mathrm{F} & \mathrm{F} \\
\mathrm{C} & \mathrm{F} \\
\mathrm{F} \\
\mathrm{F} & \mathrm{F} \\
\mathrm{F} & \mathrm{F} \\
\mathrm{F} & \mathrm{F} \\
\mathrm{F} \\
\mathrm{F} \\
\mathrm{F} & \mathrm{F} \\
\mathrm{C} \\
\mathrm{C} \\
\mathrm{C} \\
\mathrm{C} \\
\mathrm{C} \\
\mathrm{C} \\
\mathrm{C}\end{array}$ & $\begin{array}{l}R \\
R \\
R \\
F \\
F \\
F \\
F \\
F\end{array}$ & $\begin{array}{lll}\mathrm{A} & \mathrm{G} & \mathrm{X} \\
\mathrm{C} & \mathrm{G} \\
\mathrm{A} & \mathrm{G} \\
\mathrm{A} & \mathrm{G} \\
\mathrm{C} & \mathrm{G} \\
\mathrm{A} & \mathrm{G} \\
\mathrm{A} & \mathrm{G} \\
\mathrm{A} & \mathrm{G} \\
\mathrm{A} & \mathrm{G} \\
\mathrm{A} & \mathrm{G} \\
\mathrm{A} & \mathrm{G} \\
\mathrm{A} & \mathrm{G} \\
\mathrm{A} & \mathrm{G} \\
\mathrm{A} & \mathrm{G} \\
\mathrm{A} & \mathrm{G} \\
\mathrm{A} & \mathrm{G} \\
\mathrm{A} & \mathrm{G} \\
\mathrm{A} & \mathrm{G}\end{array}$ \\
\hline
\end{tabular}

Note: Not all samples studied appear in the tables. 


\section{MÜLLER}

Table 3. Distribution of calcareous nannofossils in Miocene sediments, Hole 548A. Symbols and abbreviations as in Table 2.

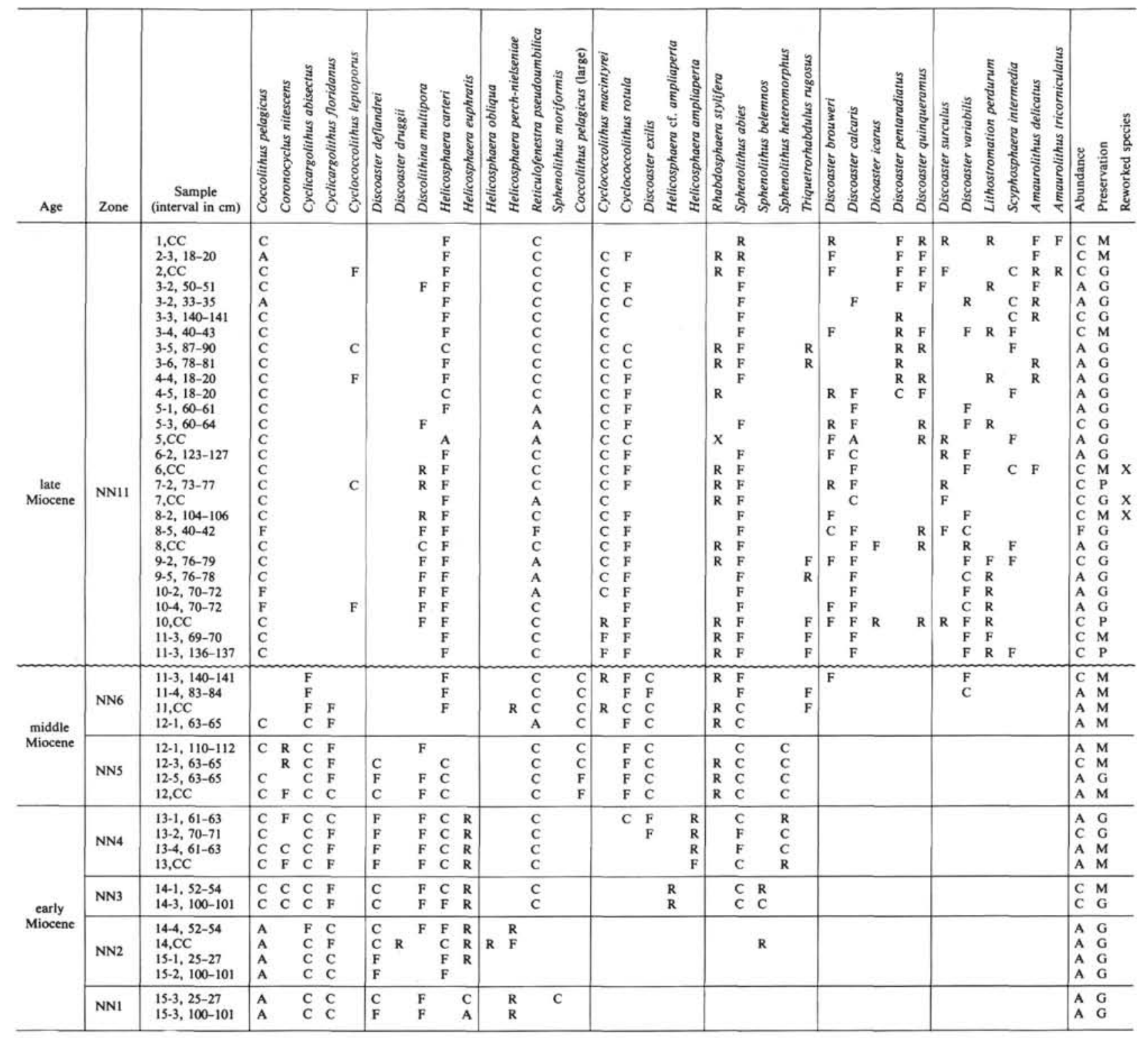

of maximum transgression and volcanic activity (Sites 549, 551, northwestern Europe). These sediments were probably deposited under stagnant conditions. Nannofossils within this interval are rare or absent, owing to dissolution, which may be linked to diagenetic processes within these sediments rich in organic matter.

The Cenomanian/Turonian boundary is determined in this report by the first occurrence of Gartnerago obliquum. Another good marker for the boundary is Podorhabdus albianus, which is frequent in the Cenomanian. According to Thierstein (1976), its last occurrence is near the base of the Turonian.

The sedimentary sequence from Turonian to Maestrichtian is condensed; this may be linked to the high sea-level stand during this period and the consequent trapping of sediments on the shelf.

\section{Coniacian-Santonian}

At Site 550 the effects of dissolution are significant within the lower part of the Coniacian-Santonian (Core 550B-15, Sections 1-3), suggesting deposition below the CCD. Further subdivision of this stratigraphic interval is not possible. It is characterized by the presence of Marthasterites furcatus and Lithastrinus grillii.

\section{Campanian}

Campanian deposition is represented by the interval between the first occurrence of Broinsonia parca and the extinction of Eiffellithus eximius. The upper Campanian can be recognized by the presence of E. eximius together with Tetralithus trifidus, T. gothicus, and T. aculeus. The upper Campanian is transgressive upon the 
Hercynian basement at Site 548. At Site 550 (Hole 550B), the Campanian may be represented by a condensed sequence (Sections 550B-13-3 to 550B-14-3), as shown by the presence of a magnetic polarity correlated with Anomaly 33 within this interval; however, because deposition took place below the $\mathrm{CCD}$, the biostratigraphic relationships are uncertain.

\section{Maestrichtian}

A complete Maestrichtian section was encountered at Site 548. The white nannofossil chalk is rich in large nannoplankton, but effects of diagenesis (fragmentation) increase with depth. The abundance of Lucianorhabdus cayeuxii indicates that these sediments were deposited in a relatively shallow environment, which is confirmed also by foraminiferal assemblages. $L$. cayeuxii is common in the turbidite layers (displaced sediments from the shelf-upper slope) of white nannofossil chalk at Site 550 , which are interbedded with the autochthonous light brown to reddish brown marly chalk. The preservation of the nannoplankton in the white chalk is different (strong recrystallization and fragmentation) from that observed in the autochthonous sediments.

No signs of dissolution were observed within the upper Maestrichtian at Site 550, indicating that the CCD was low in the late Maestrichtian.

The Cretaceous/Tertiary boundary was recovered only at Site 550 (Hole 550B). It lies within a sequence of marly chalk characterized by the occurrence of turbidites. The boundary was identified by the first occurrence of Biantholithus sparsus, accompanied by a distinct decrease in nannoplankton. This is followed upsection by a thin interval containing chiefly thoracosphaerids (calcareous dinoflagellate cysts), as has been also reported from other areas (Perch-Nielsen, 1977; Thierstein and Okada, 1979). The Cretaceous/Tertiary contact is not very distinct, because of reworking of Cretaceous nannofossils into Danian strata. At Site 550 the boundary lies between 550B-2-3, $34 \mathrm{~cm}$ and 550B-2-3, $38 \mathrm{~cm}$, just below magnetic Anomaly 29. An unconformity between the Cretaceous and the lower Paleocene (Danian) is present at the other sites $(548,549$, and 551).

\section{Tertiary}

Interpretations of relative surface-water temperature, degree of dissolution, diversity of nannoplankton assemblages, and observed unconformities are summarized in Figure 2.

\section{Paleocene}

Nannoplankton assemblages of the lowermost Paleocene (Zone NP1) are of low diversity (chiefly Markalius inversus, Zygolithus sigmoides, and Biantholithus sparsus). Perch-Nielsen (1979) described a number of other small species, and gave a detailed subdivision of the Danian. It is difficult, however, to recognize these small forms under the light microscope, or to use Perch-Nielsen's subdivision outside the region she studied (Denmark, North Sea). No signs of dissolution can be observed among lowermost Paleocene assemblages; this indicates that the CCD was low during the Cretaceous/ Tertiary transition. The chalk and limestone facies of the Danian has a wide distribution in the North Atlantic, North Sea, and northwestern Europe. The nannoplankton are abundant within these sediments, often being overgrown and broken by effects of diagenesis.

The nannoplankton assemblages of Zone NP3 recovered from the sites on the Goban Spur are characterized by the abundance of Braarudosphaera bigelowi (Sites 548 and 549), which sometimes occurs with Thoracosphaera deflandrei (Müller, 1979a). This relationship has been described also on the basis of samples from many other sites in the North and South Atlantic (Perch-Nielsen, 1977). The abundance of Braarudosphaera bigelowi may indicate that these sediments were deposited in an environment of relatively shallow water close to the continent. This species is very rare at Site 550 , located on the abyssal plain. Since the nannofossils within these sediments do not show signs of etching, the scarcity of $B$. bigelowi at Site 550 cannot be explained by dissolution.

A middle Paleocene unconformity, representing hiatuses of varying length, was recovered at all sites drilled during Leg 80. It was also detected by results from Leg 48 (Müller, 1979a), and by investigations in the northwest European Tertiary basins, where this unconformity represents the interval from nannoplankton Zone NP4 to Zone NP7. This unconformity coincides with a minor global unconformity about 56 m.y. old (Vail and Hardenbol, 1979). Sediments of nannoplankton Zone NP8 are transgressive in the marginal northwest European basins, being known from the Paris Basin, London Basin, northwestern Germany, and Denmark. The upper Paleocene nannoplankton assemblages are of high diversity, indicating relatively warm water. Siliceous microfossils are common in Zone NP8 and the lower part of Zone NP9; this may be related to the influence of volcanic ash (Sites 549 and 550), and can be compared to the time-equivalent Mohler Formation in Denmark, which is also rich in siliceous microfossils and volcanic ash. If this correlation is correct, the Mohler Formation would be restricted to the stratigraphic interval of nannoplankton Zones NP8 to NP9.

\section{Eocene}

Thick, almost complete lower to middle Eocene sequences were deposited in the northeastern Atlantic (Legs 48 and 80 ). This interval is characterized by a lithologic change within nannoplankton Zone NP14 from calcareous mudstone (lower Eocene) to siliceous nannofossil ooze (middle Eocene). The change seems to be typical for the entire North Atlantic (Berggren and Hollister, 1974). It was not observed, however, at Site 548 , located in a relatively shallow-water paleoenvironment (about $1000 \mathrm{~m}$ ), or in the northwest European epicontinental basins.

A short hiatus around the lower/middle Eocene boundary, representing the interval of nannoplankton Zone NP13, was recognized at Site 548 (upper slope), and coincides with a major unconformity (Vail and Hardenbol, 1979).

The nannoplankton assemblages of lower and middle Eocene sediments are of high diversity. The associations indicate warm water with slight fluctuations during mid- 
Table 4. Distribution of calcareous nannofossils in Paleogene sediments, Hole 548A. Symbols and abbreviations as in Table 2.

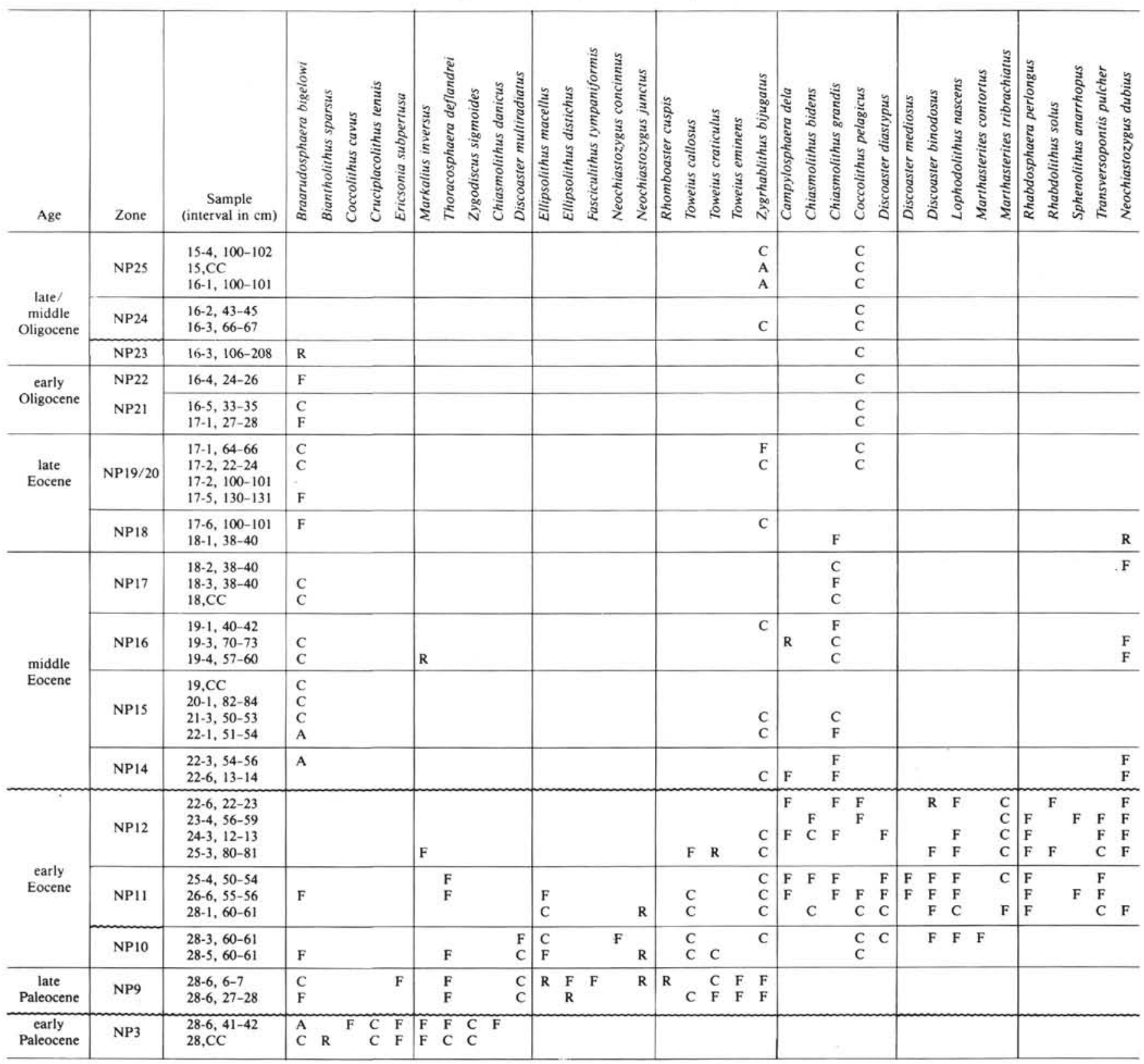

dle Eocene time (Müller, 1979a). A rise of the CCD was recorded at Site 550 within nannoplankton Zones NP13-NP14. This may have been caused by the establishment of deep cold-water circulation in the North Atlantic about 50 m.y. ago (Vergnaud Grazzini et al., 1979), and by a slight decrease of surface water temperature (Müller, 1979a).

No distinct latitudinal differentiation of the nannoplankton assemblages can be discerned for latest Paleocene and early Eocene time. The lower Eocene nannoplankton associations described on the basis of samples from the Norwegian-Greenland Sea (Müller, 1976) are the same as those known from the northwest European epicontinental basins and from the North Atlantic. There is a difference only in the abundance of species typical of shallower water, such as Transversopontis pulcher,
Micrantholithus mirabilis, and Imperiaster obscurus. The lesser abundance of discoasters is known also from the German Tertiary basin and the Rockall Bank (Müller, 1979a) and results from deposition of these sediments in a relatively shallow environment and a high input of terrigenous material.

The determination of the nannoplankton zones as defined in the standard zonation (Martini, 1971) is possible without any difficulties in the Paleogene section. Only the boundary between Zones NP15 and NP16, defined by the extinction of Blackites gladius, cannot be recognized, because this species has not been found, although it is generally common in the northwest European basins. The common occurrence of Discoaster tani nodifer has been used in this chapter for the subdivision of Zones NP15 and NP16. Chiasmolithus gigas and Dis- 
Table 4. (Continued).

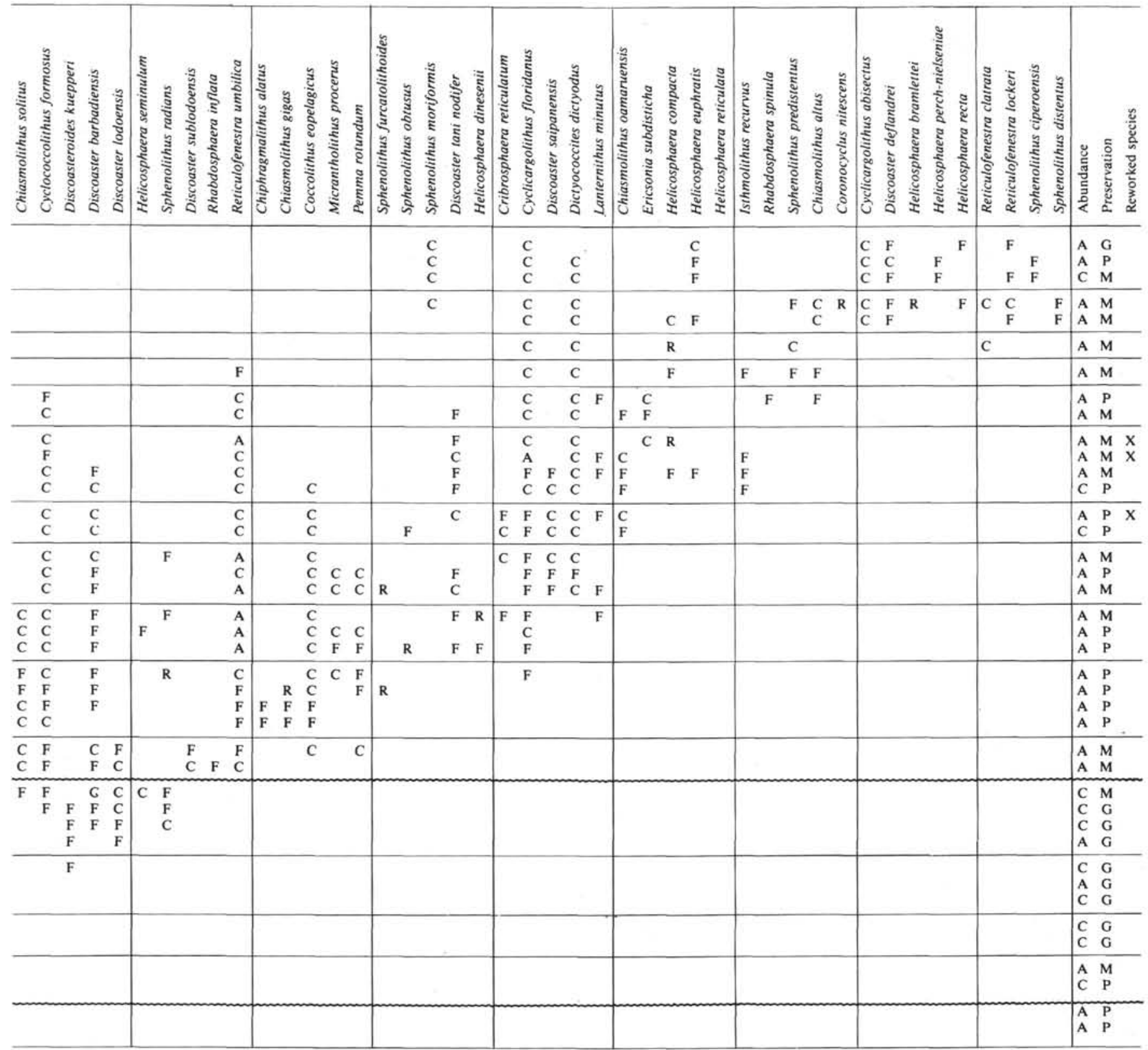

coaster martinii are useful markers for Zone NP15, since both species are restricted to this stratigraphic interval, although they are never frequent.

Middle and upper Eocene sediments at Site 548 are characterized by an abundance of Braarudosphaera bigelowi, Micrantholithus procerus, Pemma rotundum, and Zygrhablithus bijugatus. Discoasters are few to rare. These observations may indicate that deposition of these sediments took place in relatively shallow water (outer shelf-upper slope), which shows that Site 548 underwent only slow subsidence from Campanian time to the Eocene.

Chiasmolithus solitus and Chiasmolithus grandis are common in several layers, which may indicate changes of surface-water temperature. However, it seems that this genus has changed its habitat, being a typical cool-water form only since late Eocene time.

A very condensed section (Sites 548 and 549) or a short hiatus (Leg 48: Sites 400, 401, and 406) represents the interval of nannoplankton Zone NP17. Also at Sites 548 and 549 , a hiatus is indicated by a deflection of the accumulation-rate curve. This short hiatus could coincide with a major unconformity about $40 \mathrm{~m}$.y. old, described by Vail and Hardenbol (1979).

Complete upper Eocene sections were encountered at Sites 545 and 549. Site 550 was below the carbonate compensation depth during the late Eocene. Subdivision of the upper Eocene nannoplankton Zones NP19 and NP20 is difficult, and not always possible. Sphenolithus pseudoradians is absent in the northeastern At- 
Table 5. Distribution of calcareous nannofossils in Cretaceous sediments, Hole 548A. Symbols and abbreviations as in Table 2. Less certain boundaries are dashed.

\begin{tabular}{|c|c|c|c|c|c|c|c|c|c|c|c|c|c|c|c|c|c|c|c|}
\hline Age & Zone & $\begin{array}{c}\text { Sample } \\
\text { (interval in } \mathrm{cm} \text { ) }\end{array}$ & 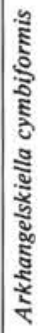 & 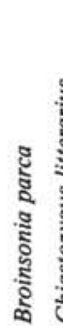 & 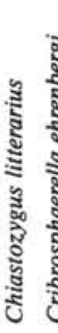 & 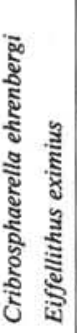 & 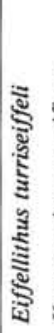 & 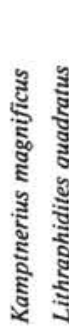 & 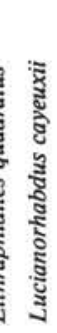 & 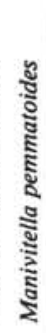 & 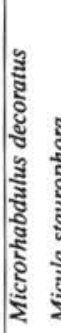 & 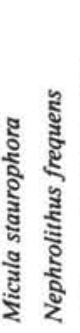 & 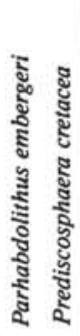 & 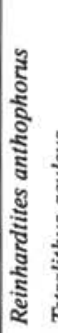 & 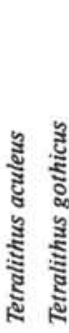 & है & 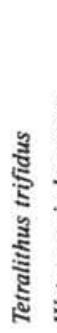 & 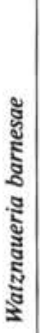 & 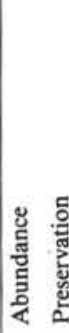 \\
\hline $\begin{array}{c}\text { late } \\
\text { Maestrichtian }\end{array}$ & $\begin{array}{l}\text { Micula } \\
\text { mura }\end{array}$ & $\begin{array}{l}29-1,1-2 \\
29-2,50-51 \\
29-3,50-51 \\
29-4,100-101 \\
29, C C \\
30-3,89-91 \\
30, C C\end{array}$ & $\begin{array}{l}\text { C } \\
\text { A } \\
\text { C } \\
\text { A } \\
\text { A } \\
\text { A } \\
\text { A }\end{array}$ & & 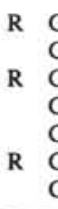 & $\begin{array}{l}\mathrm{C} \\
\mathrm{C} \\
\mathrm{C} \\
\mathrm{C} \\
\mathrm{C} \\
\mathrm{C} \\
\mathrm{C}\end{array}$ & $\begin{array}{l}\text { C } \\
\text { F } \\
\text { C } \\
\text { C } \\
\text { F }\end{array}$ & $\begin{array}{ll}\text { F } & \text { C } \\
\text { F } & \text { F } \\
\text { F } & \text { F } \\
\text { F } & \text { C } \\
\text { F } & \text { C } \\
\text { F } & \text { C } \\
\text { F } & \text { F }\end{array}$ & C & $\begin{array}{l}\text { F } \\
\text { F } \\
\text { F } \\
\text { F } \\
\text { R }\end{array}$ & $\begin{array}{l}\mathrm{C} \\
\mathrm{F} \\
\mathrm{F} \\
\mathrm{C} \\
\mathrm{F} \\
\mathrm{F}\end{array}$ & $\begin{array}{ll}\mathrm{F} & \\
\mathrm{F} & \\
\mathrm{F} & \mathrm{R} \\
& \mathrm{F} \\
\mathrm{F} & \\
\mathrm{F} & \end{array}$ & $\begin{array}{ll}\mathrm{R} & \mathrm{C} \\
& \mathrm{A} \\
\mathrm{F} & \mathrm{F} \\
\mathrm{F} & \mathrm{A} \\
& \mathrm{C} \\
& \mathrm{C} \\
& \mathrm{C}\end{array}$ & & $\mathbf{R}$ & $\begin{array}{l}\mathrm{F} \\
\mathrm{F} \\
\mathrm{F} \\
\mathrm{F} \\
\mathrm{F} \\
\mathrm{F} \\
\mathrm{R}\end{array}$ & & $\begin{array}{l}\mathrm{F} \\
\mathrm{F} \\
\mathrm{F}\end{array}$ & $\begin{array}{ll}\mathrm{A} & \mathrm{G} \\
\mathrm{A} & \mathrm{G} \\
\mathrm{A} & \mathrm{M} \\
\mathrm{A} & \mathrm{M} \\
\mathrm{A} & \mathrm{G} \\
\mathrm{A} & \mathrm{M} \\
\mathrm{A} & \mathrm{M}\end{array}$ \\
\hline $\begin{array}{c}\text { middle } \\
\text { Maestrichtian }\end{array}$ & $\begin{array}{l}\text { Lithraphidites } \\
\text { quadratus }\end{array}$ & $\begin{array}{l}31-1,70-72 \\
31-3,70-72 \\
32-1,70-72 \\
32, \mathrm{CC}\end{array}$ & $\begin{array}{l}\text { A } \\
\text { A } \\
\text { A } \\
\text { A }\end{array}$ & F & c & $\begin{array}{l}\text { C } \\
\text { C } \\
\text { C } \\
\text { C }\end{array}$ & $\begin{array}{l}\mathrm{F} \\
\mathrm{F} \\
\mathrm{F} \\
\mathrm{C}\end{array}$ & $\begin{array}{ll}F & F \\
F & F \\
F & F \\
F & F\end{array}$ & F & $\begin{array}{l}\text { F } \\
F \\
F\end{array}$ & \begin{tabular}{|l}
$\mathbf{R}$ \\
$\mathrm{R}$ \\
$\mathrm{F}$ \\
\end{tabular} & F & $\begin{array}{l}\mathrm{C} \\
\mathrm{C}\end{array}$ & C & R & & & $\begin{array}{l}\mathrm{F} \\
\mathrm{F} \\
\mathrm{F} \\
\mathrm{F}\end{array}$ & $\begin{array}{ll}\mathrm{A} & \mathrm{M} \\
\mathrm{A} & \mathrm{P} \\
\mathrm{A} & \mathrm{P} \\
\mathrm{A} & \mathrm{M}\end{array}$ \\
\hline $\begin{array}{c}\text { early } \\
\text { Maestrichtian }\end{array}$ & $\begin{array}{l}\text { Tetralithus } \\
\text { trifidus }\end{array}$ & $\begin{array}{l}33-3,6-7 \\
33-4,6-7 \\
34-2,26-27 \\
34-4,26-27 \\
34, \mathrm{CC}\end{array}$ & $\begin{array}{l}\mathrm{C} \\
\mathrm{C} \\
\mathrm{C} \\
\mathrm{C} \\
\mathrm{C}\end{array}$ & $\begin{array}{l}\mathrm{F} \\
\mathrm{C} \\
\mathrm{C} \\
\mathrm{C} \\
\mathrm{C}\end{array}$ & C & $\begin{array}{l}\mathrm{C} \\
\mathrm{C} \\
\mathrm{C} \\
\mathrm{F} \\
\mathrm{F}\end{array}$ & $\begin{array}{l}\mathrm{F} \\
\mathrm{F} \\
\mathrm{F} \\
\mathrm{F} \\
\mathrm{F}\end{array}$ & & $\begin{array}{l}\text { C } \\
\text { C } \\
\text { C } \\
\text { A } \\
\text { C }\end{array}$ & $\begin{array}{l}\text { F } \\
\text { F }\end{array}$ & $\begin{array}{l}\text { C } \\
\text { F }\end{array}$ & $\begin{array}{l}\text { F } \\
\text { C } \\
\text { F } \\
\text { F }\end{array}$ & $\begin{array}{l}\mathrm{C} \\
\mathrm{C} \\
\mathrm{C} \\
\mathrm{C} \\
\mathrm{C}\end{array}$ & $\begin{array}{l}\mathrm{C} \\
\mathrm{F} \\
\mathrm{C} \\
\mathrm{C} \\
\mathrm{C}\end{array}$ & $\begin{array}{ll} & \mathrm{R} \\
& \mathrm{F} \\
& \mathrm{F} \\
& \mathrm{F} \\
\mathrm{F} & \mathrm{R}\end{array}$ & $\begin{array}{l}R \\
F \\
F \\
F\end{array}$ & $\begin{array}{l}\mathrm{F} \\
\mathrm{F} \\
\mathrm{R} \\
\mathrm{F}\end{array}$ & $\begin{array}{l}\mathrm{C} \\
\mathrm{F} \\
\mathrm{F}\end{array}$ & $\begin{array}{ll}\mathrm{A} & \mathrm{P} \\
\mathrm{A} & \mathrm{P} \\
\mathrm{A} & \mathrm{M} \\
\mathrm{A} & \mathrm{M} \\
\mathrm{A} & \mathrm{M}\end{array}$ \\
\hline $\begin{array}{c}\text { late } \\
\text { Campanian }\end{array}$ & & $\begin{array}{l}35-1,45-46 \\
35, \mathrm{CC}\end{array}$ & $\begin{array}{l}\mathrm{C} \\
\mathrm{C}\end{array}$ & $\begin{array}{l}\mathrm{C} \\
\mathrm{C}\end{array}$ & F & $\begin{array}{|ll|}\mathrm{C} & \mathrm{F} \\
\mathrm{F} & \mathrm{F}\end{array}$ & $\begin{array}{l}\mathrm{F} \\
\mathrm{C}\end{array}$ & $\begin{array}{l}\mathrm{F} \\
\mathrm{F}\end{array}$ & $\begin{array}{l}\mathrm{C} \\
\mathrm{A}\end{array}$ & $F$ & C & & $\begin{array}{l}\mathrm{C} \\
\mathrm{C}\end{array}$ & $\begin{array}{l}\mathrm{F} \\
\mathrm{C}\end{array}$ & $\mathbf{R}$ & & R & $C$ & $\begin{array}{ll}\text { A } & M \\
\text { A } & M\end{array}$ \\
\hline
\end{tabular}

lantic, but the first occurrence of Helicosphaera reticulata may be a good biostratigraphic event for determining the base of Zone NP20.

The Eocene/Oligocene boundary (according to distribution of calcareous nannoplankton) is determined by the extinction of Discoaster saipanensis and/or Discoaster barbadiensis. Both species are rare in the uppermost Eocene, probably because of decreasing water temperature. The boundary was encountered at Sites 548 and 549. It lies in the middle of foraminiferal Zone P17. The boundary NP20/NP21 at Site 549 corresponds to the last common occurrence of Globorotalia cerroazulensis (Snyder et al., this vol.). In areas where discoasters occur only sporadically or are absent within the upper Eocene (northern and southern high latitudes or in shallow basins), it is possible to use the extinction of Cribrocentrum reticulatum for the approximate determination of the Eocene/Oligocene boundary. This species has its last occurrence within the uppermost part of nannoplankton Zone NP20 (Müller, 1978a). Shafik (1981) mentioned the last occurrence of $C$. reticulatum within the upper part of foraminiferal Zone P16 in Australia. At Site $549, C$. reticulatum disappears slightly below the Eocene/Oligocene boundary; this observation is confirmed by study of the Eocene/Oligocene sections of Barbados (Müller, unpublished). This species occurs in tropical and high-latitude areas, and is resistant to dissolution. Two variations of $C$. reticulatum are known: (1) a large one with a smaller central opening, found mainly in tropical areas (Barbados), and (2) a smaller form with a large central area, common in temperate and cold water, such as the North Atlantic and north- western Europe. Another species observed in the upper Eocene sediments of the temperate zone is Corannulus germanicus. At Site 549 this species has its first occurrence in Zone NP19 and ranges up to the lower Oligocene (NP21). Its cold-water affinities may be confirmed by greater abundance in layers characterized by common cold-water species such as Isthmolithus recurvus, Chiasmolithus oamaruensis, and Zygrhablithus bijugatus.

\section{Oligocene}

A rather thick sequence of lower Oligocene sediments (nannoplankton Zones NP21-NP22) was recovered at Site 549. The nannoplankton assemblages are well preserved to slightly overgrown. A strong cooling (about $5^{\circ} \mathrm{C}$ ), mainly of the deep water, is indicated by a distinct increase of heavy oxygen isotopes in the early Oligocene, nannoplankton Zone NP21 (Buchardt, 1978; Rabussier-Lointier, 1980; Cavelier et al., 1981). This may be related to the development of sea-ice around Antarctica in response to the isolation of Antarctica from Australia about 40 m.y. ago (Kennett, 1977).

A distinct decrease of accumulation rate or an unconformity characterizes the middle Oligocene sequences recovered during Legs 80 and 48 . A rise of the carbonate compensation depth is represented at Site 550, corresponding to the interval of nannoplankton Zones NP22 and NP23. An erosional unconformity representing the interval of the lowermost part of Zone NP24 and Zone NP23 was encountered at Site 548 and probably at Site 549, where a condensed sequence represents Zone NP23. A condensed section was also recovered at Site 


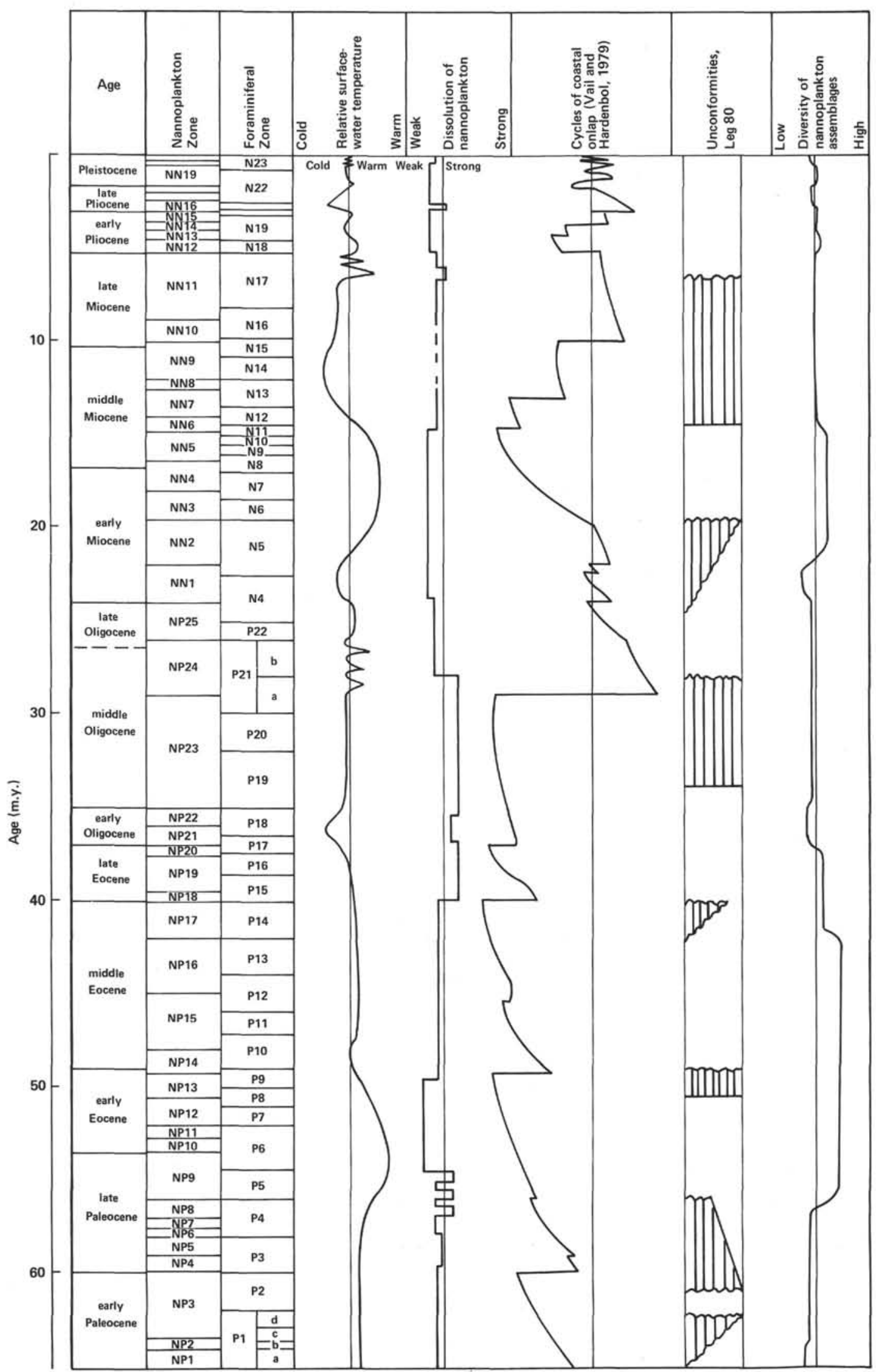

Figure 2. Summary of nannoplankton zonation at Leg 80 drill sites, showing relative surface-water temperature during the Tertiary, dissolution of nannoplankton remains, changes of coastal onlap, unconformities at Leg 80 sites (vertical striping), and diversity of nannoplankton assemblages. 
Table 6. Distribution of calcareous nannofossils in upper Eocene to Pleistocene sediments, Hole 549A. Symbols and abbreviations as in Table 5.

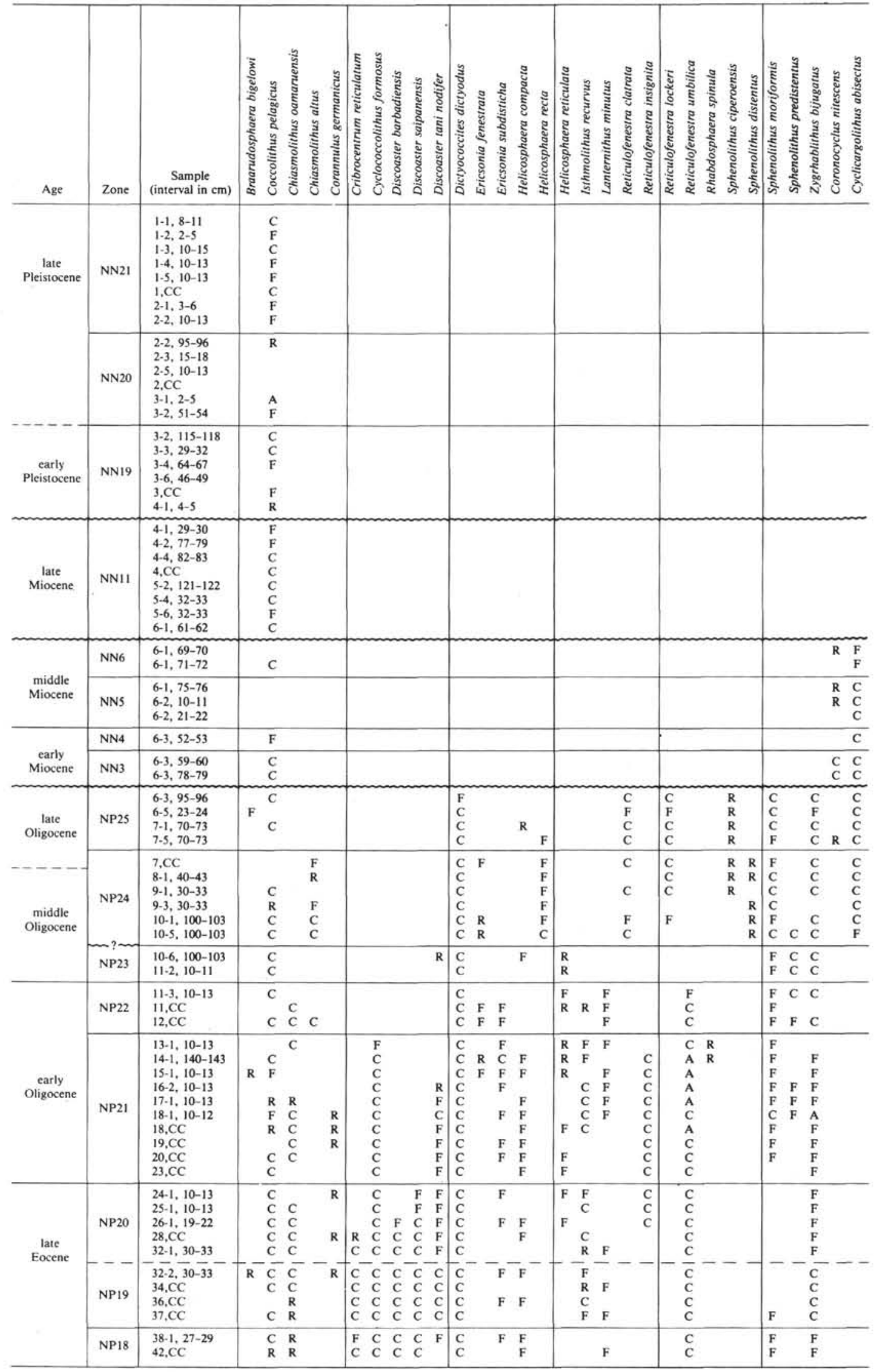


Table 6. (Continued).

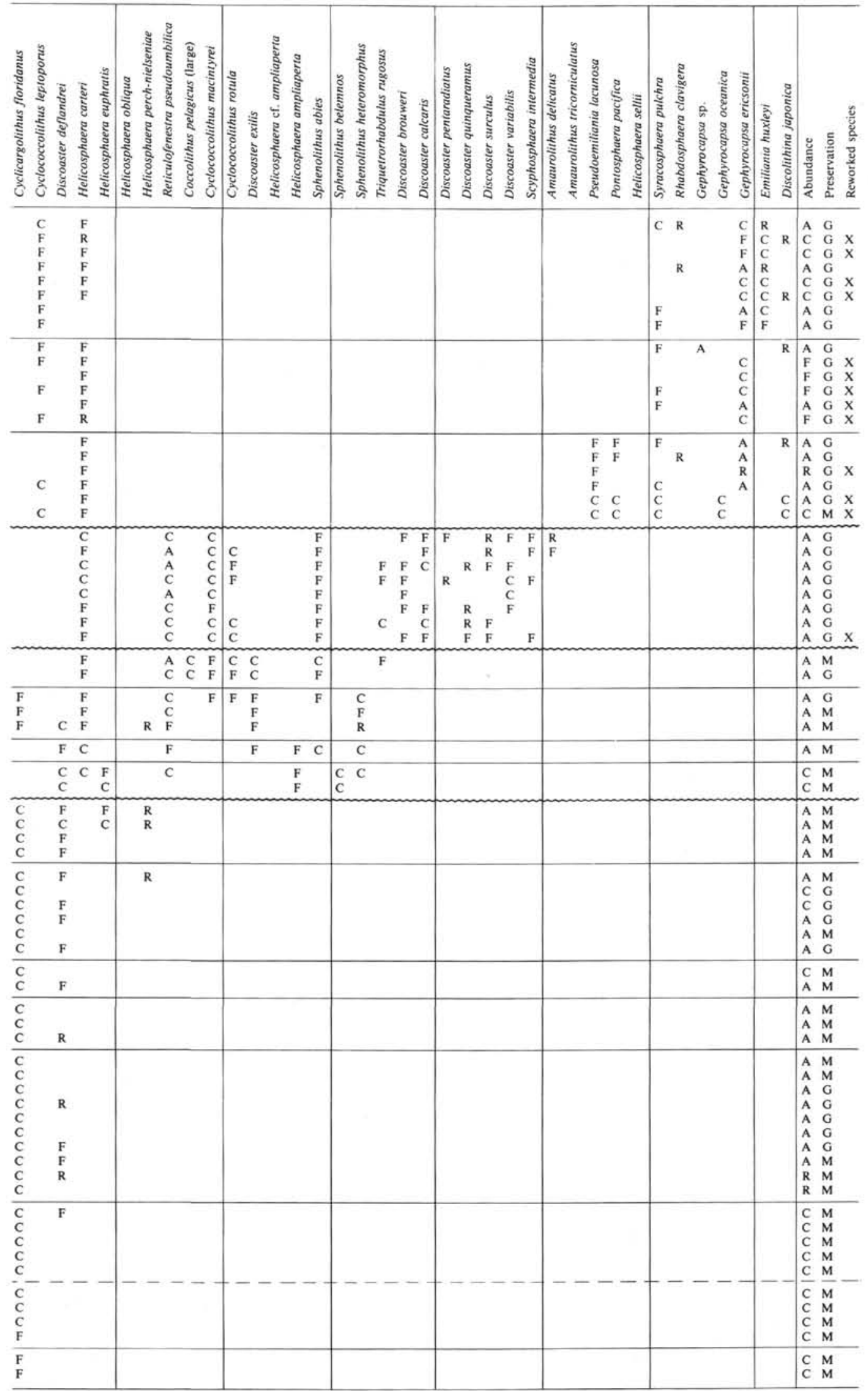


Table 7. Distribution of calcareous nannofossils in Paleocene to upper Eocene sediments, Hole 549. Symbols and abbreviations as in Table 5.

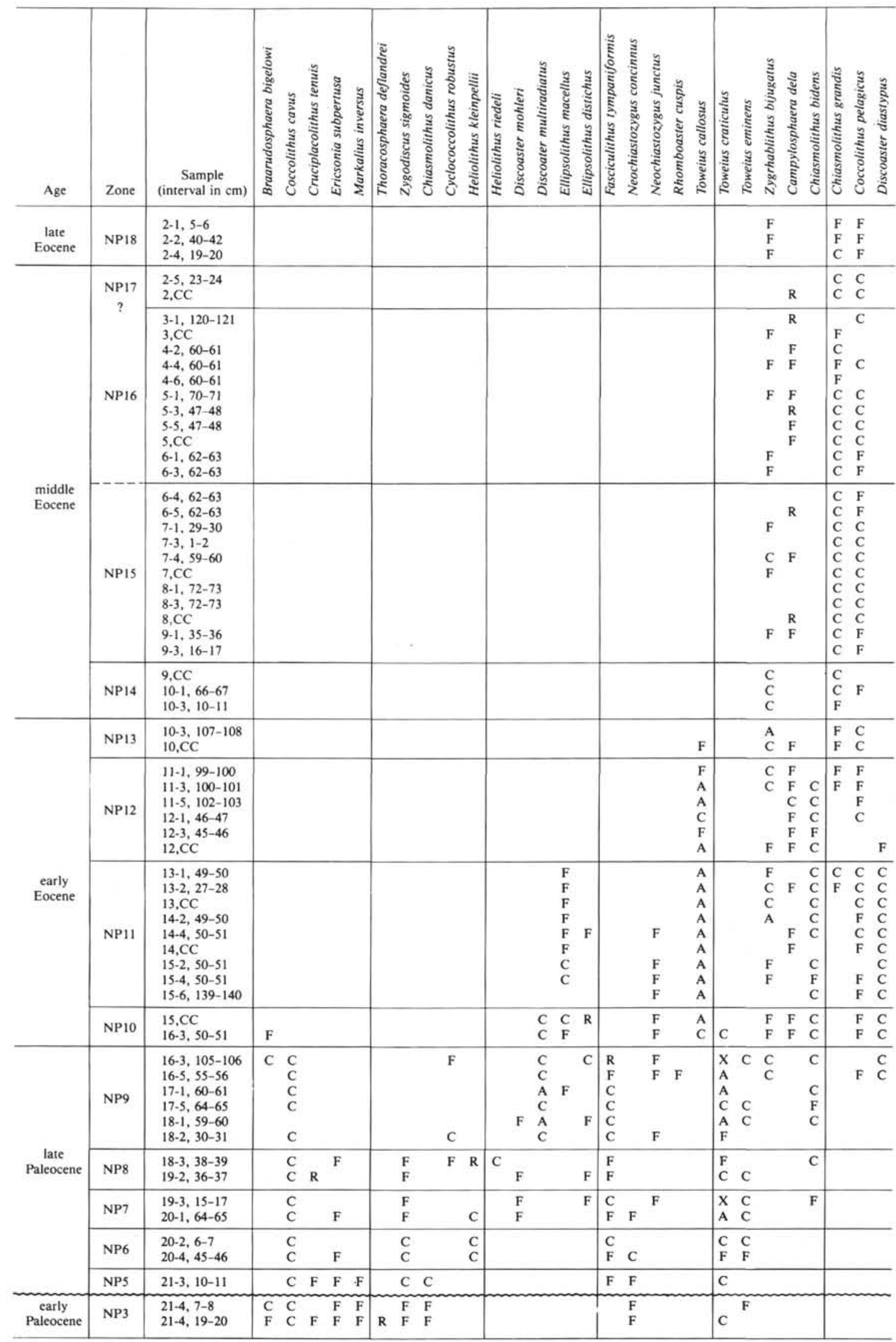


Table 7. (Continued).

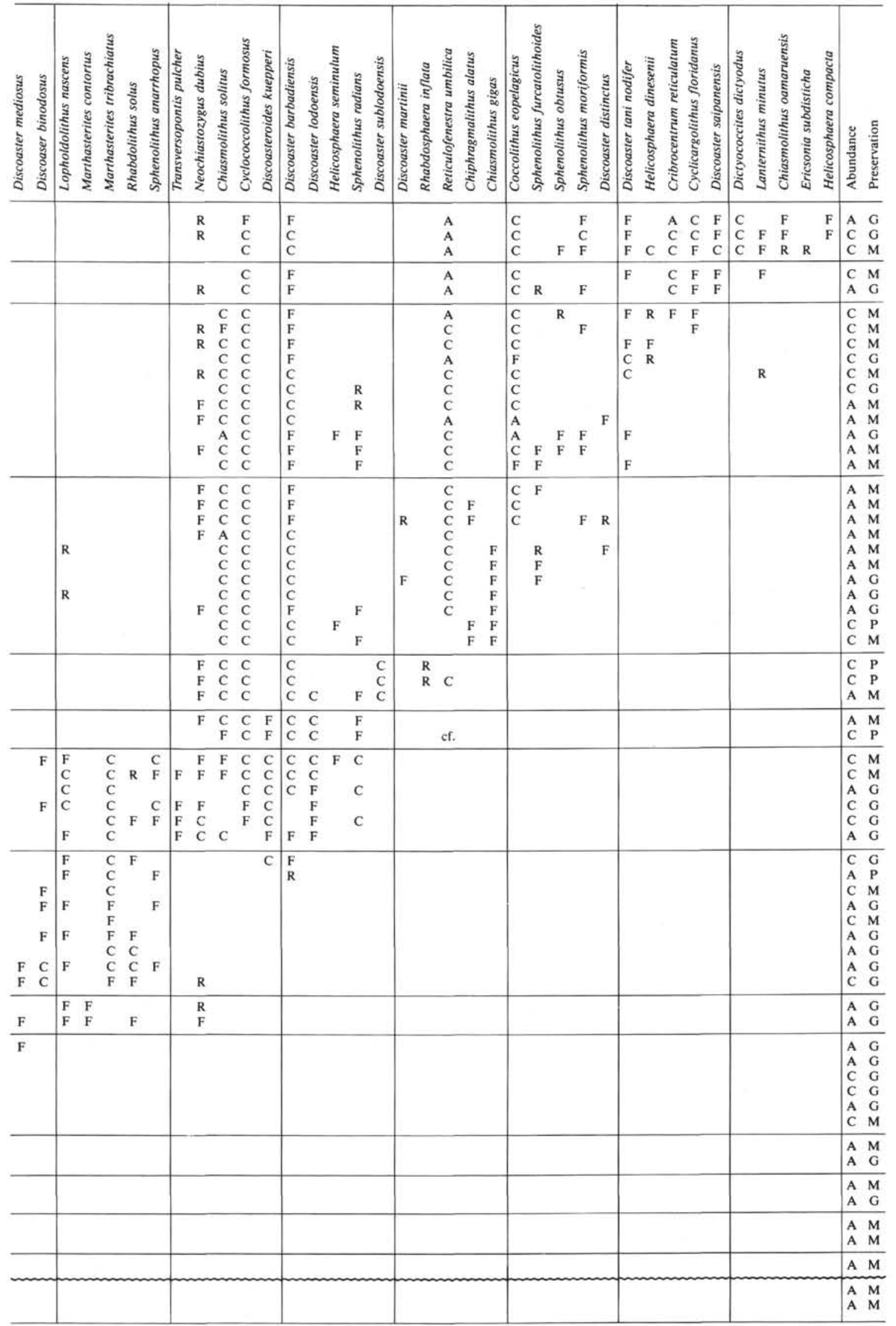


Table 8. Distribution of calcareous nannofossils in Cretaceous sediments, Hole 549. Symbols and abbreviations as in Table 2 .

\begin{tabular}{|c|c|c|c|c|c|c|c|c|c|c|c|c|c|c|c|c|c|c|c|}
\hline Age & Zone & $\begin{array}{c}\text { Sample } \\
\text { (interval in } \mathrm{cm} \text { ) }\end{array}$ & 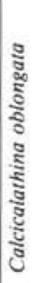 & $\begin{array}{l}\text { हूँ } \\
\text { हूँ } \\
\text { हूँ } \\
\text { ปूँ } \\
\text { हूँ }\end{array}$ & 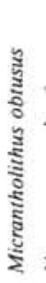 & 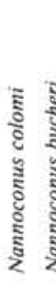 & 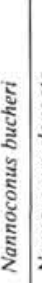 & 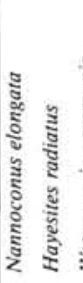 & 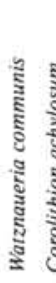 & 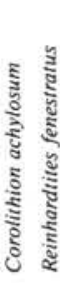 & 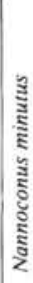 & 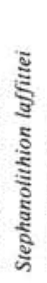 & 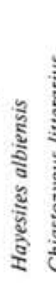 & 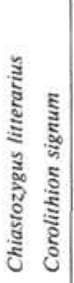 & 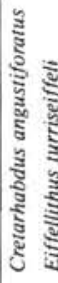 & 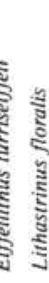 & 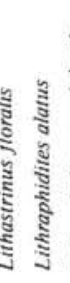 & 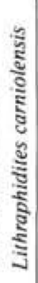 & 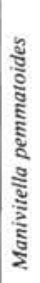 \\
\hline $\begin{array}{c}\text { late } \\
\text { Maestrichtian }\end{array}$ & $\begin{array}{l}\text { Micula } \\
\text { mura }\end{array}$ & $\begin{array}{l}21-4,25-26 \\
21, C C \\
22-1,41-42\end{array}$ & & & & & & & & & & & & & $\begin{array}{l}\mathrm{F} \\
\mathrm{C} \\
\mathrm{F}\end{array}$ & F & & & \\
\hline $\begin{array}{c}\text { early } \\
\text { Maestrichtian }\end{array}$ & $\begin{array}{c}\text { Tetralithus } \\
\text { trifidus }\end{array}$ & $\begin{array}{l}22-2,50-51 \\
22-3,80-81 \\
22-5,30-31 \\
23-1,45-46 \\
23-3,28-29\end{array}$ & & & & & & & & & & & & & $\begin{array}{l}\mathrm{F} \\
\mathrm{F} \\
\mathrm{C} \\
\mathrm{C} \\
\mathrm{C}\end{array}$ & F & & $\mathrm{F}$ & $\begin{array}{l}\mathrm{F} \\
\mathrm{F} \\
\mathrm{C} \\
\mathrm{F}\end{array}$ \\
\hline Campanian & $\begin{array}{c}\begin{array}{c}\text { Broinsonia } \\
\text { parca }\end{array} \\
\end{array}$ & $\begin{array}{l}23-4,46-47 \\
23, C C\end{array}$ & & & & & & & & & & & & & F & c & & & $\begin{array}{l}\mathrm{C} \\
\mathrm{F} \\
\end{array}$ \\
\hline $\begin{array}{l}\text { Santonian/ } \\
\text { Coniacian }\end{array}$ & $\begin{array}{l}\text { Martha- } \\
\text { sterites } \\
\text { furcatus }\end{array}$ & $\begin{array}{l}24-1,46-47 \\
24-2,12-13 \\
24, C \mathrm{C} \\
25-1,30-31 \\
25, \mathrm{CC}\end{array}$ & & & & & & & & & & $\begin{array}{l}\mathrm{F} \\
\mathrm{F}\end{array}$ & & $\begin{array}{l}\mathrm{F} \\
\mathrm{F}\end{array}$ & & $\begin{array}{ll}\mathrm{F} & \\
\mathrm{F} & \mathrm{F} \\
\mathrm{C} & \mathrm{R} \\
\mathrm{F} & \mathrm{F}\end{array}$ & $\begin{array}{l}F \\
\text { R } \\
\text { F }\end{array}$ & $\begin{array}{l}\mathrm{F} \\
\mathrm{F} \\
\mathrm{F}\end{array}$ & $\begin{array}{l}\text { C } \\
\text { F } \\
\text { F } \\
\text { C } \\
\text { F } \\
\end{array}$ \\
\hline Turonian & & $\begin{array}{l}26-1,18-19 \\
26, C C \\
27-1,\end{array}$ & & & & & & & & & & $R$ & & $\mathbf{F}$ & & $\begin{array}{ll}F & C \\
F & C \\
F & F \\
\end{array}$ & $\begin{array}{l}\mathrm{C} \\
\mathrm{C} \\
\mathrm{F}\end{array}$ & $\begin{array}{l}\mathrm{F} \\
\mathrm{F}\end{array}$ & $\begin{array}{l}\mathrm{C} \\
\mathrm{F} \\
\mathrm{F}\end{array}$ \\
\hline $\begin{array}{c}\text { middle } \\
\text { Cenomanian }\end{array}$ & $\begin{array}{c}\text { Lithra- } \\
\text { phidites } \\
\text { alatus }\end{array}$ & $\begin{array}{l}28-1,67-68 \\
28-2,79-80 \\
28, \mathrm{CC} \\
29-1,13-14 \\
29, \mathrm{CC} \\
30, \mathrm{CC}\end{array}$ & & & & & & & $\mathrm{F}$ & & & & & $\begin{array}{ll}\mathrm{F} & \mathrm{R} \\
& \mathrm{R} \\
& \\
\mathrm{F} & \end{array}$ & & $\begin{array}{ll}F & F \\
F & F \\
F & \\
F & \\
F & R \\
\end{array}$ & $\begin{array}{l}\text { F cf. } \\
\text { cf. }\end{array}$ & $\begin{array}{l}\mathrm{F} \\
\mathrm{F}\end{array}$ & $\begin{array}{l}\mathrm{F} \\
\mathrm{F} \\
\mathrm{F} \\
\mathrm{F} \\
\mathrm{F} \\
\end{array}$ \\
\hline $\begin{array}{l}\text { middle } \\
\text { Albian }\end{array}$ & $\begin{array}{l}\text { Predisco- } \\
\text { sphaera } \\
\text { cretacea }\end{array}$ & $\begin{array}{l}31, \mathrm{CC} \\
33, \mathrm{CC} \\
34, \mathrm{CC} \\
35-1,41-42 \\
35, \mathrm{CC} \\
36, \mathrm{CC} \\
37-2,26-27 \\
37, \mathrm{CC} \\
38, \mathrm{CC} \\
39-1,30-31 \\
39, \mathrm{CC} \\
40-1,1-3 \\
40, \mathrm{CC} \\
42-1,59-60 \\
42-3,66-67 \\
42, \mathrm{CC} \\
43-1,31-32 \\
43-2,77-78 \\
43-3,93-94 \\
44-1,112-113 \\
44, \mathrm{CC} \\
45-1,55-56 \\
45-3,37-38 \\
45, \mathrm{CC} \\
46-2,20-21 \\
46, \mathrm{CC} \\
47-2,20-21 \\
47, \mathrm{CC} \\
48, \mathrm{CC} \\
49-2,85-86 \\
49-5,91-93 \\
50, \mathrm{CC} \\
\end{array}$ & & & & & & & $\begin{array}{ll}\mathrm{F} \\
\mathrm{F} \\
\mathrm{F}\end{array}$ & $\begin{array}{l}\mathrm{F} \\
\mathrm{F} \\
\mathrm{R} \\
\mathrm{R} \\
\mathrm{R}\end{array}$ & $\begin{array}{l}\mathrm{F} \\
\mathrm{R} \\
\mathrm{R} \\
\mathrm{R} \\
\mathrm{R} \\
\mathrm{F}\end{array}$ & $\begin{array}{l}F \\
F \\
F \\
F \\
F \\
F \\
F \\
F \\
F \\
F \\
F \\
F \\
F \\
F \\
F \\
F \\
F \\
F \\
\end{array}$ & $\begin{array}{ll}\mathrm{R} \\
\mathrm{R}\end{array}$ & $\begin{array}{l}\mathrm{F} \\
\mathrm{F} \\
\mathrm{F} \\
\mathrm{F} \\
\mathrm{F} \\
\mathrm{F} \\
\mathrm{F} \\
\mathrm{F}\end{array}$ & $\mathrm{F}$ & $\begin{array}{l}\text { F } \\
F \\
F\end{array}$ & $\begin{array}{l}F \\
F \\
F \\
F \\
F \\
F\end{array}$ & $\begin{array}{l}\mathrm{F} \\
\mathrm{F} \\
\mathrm{F} \\
\mathrm{F} \\
\mathrm{F}\end{array}$ & $\begin{array}{l}\mathrm{F} \\
\mathrm{F} \\
\mathrm{F} \\
\mathrm{F} \\
\mathrm{F} \\
\mathrm{F} \\
\mathrm{F} \\
\mathrm{F} \\
\mathrm{F} \\
\mathrm{F}\end{array}$ \\
\hline $\begin{array}{c}\text { middle } \\
\text { to } \\
\text { early } \\
\text { Barremian }\end{array}$ & $\begin{array}{c}\text { Lithra- } \\
\text { phidites } \\
\text { bollii }\end{array}$ & $\begin{array}{l}53-1,50-51 \\
53-3,17-18 \\
53, C C \\
54-1,7-8 \\
54-3,139-140 \\
55-1,38-39 \\
55-4,52-53 \\
56-1,38-39 \\
56, C C \\
57-2,143-144 \\
58-2,34-37 \\
58-5,84-85 \\
59-3,106-108 \\
60-3,27-28 \\
61-4,13-14 \\
70-1 \text { to } 88, C C\end{array}$ & $\begin{array}{l}\mathrm{F} \\
\mathrm{F} \\
\mathrm{F} \\
\mathrm{F} \\
\mathrm{F} \\
\mathrm{F} \\
\\
\mathrm{F} \\
\mathrm{F} \\
\mathrm{F}\end{array}$ & $\begin{array}{l}\mathrm{F} \\
\mathrm{F} \\
\mathrm{F} \\
\mathrm{F} \\
\mathrm{F} \\
\mathrm{F} \\
\mathrm{F} \\
\mathrm{R} \\
\mathrm{R} \\
\mathrm{R} \\
\mathrm{R}\end{array}$ & $\begin{array}{l}\text { F } \\
\text { C } \\
\text { F } \\
\text { C } \\
\text { C } \\
\text { F } \\
\\
\text { F } \\
\text { C } \\
\text { C } \\
\text { C } \\
\text { C } \\
\text { C } \\
\text { F }\end{array}$ & $\begin{array}{ll}\mathrm{F} & \\
& \\
\mathrm{C} & \mathrm{R} \\
\mathrm{C} & \mathrm{R} \\
\mathrm{F} & \\
\mathrm{C} & \\
\mathrm{C} & \mathrm{R} \\
\mathrm{C} & \\
\mathrm{F} & \\
\mathrm{F} & \\
\mathrm{C} & \\
\mathrm{C} & \mathrm{R} \\
\mathrm{F} & \mathrm{R}\end{array}$ & $\begin{array}{l}\mathrm{R} \\
\mathrm{R} \\
\mathrm{R}\end{array}$ & $\mathbf{R}$ & $\begin{array}{l}\mathrm{F} \\
\mathrm{F} \\
\mathrm{F}\end{array}$ & $\begin{array}{l}F \\
R \\
F\end{array}$ & & $\begin{array}{l}F \\
F \\
F \\
F \\
R \\
R\end{array}$ & & & $\begin{array}{l}\mathrm{F} \\
\mathrm{F} \\
\mathrm{F} \\
\mathrm{F} \\
\mathrm{F} \\
\mathrm{F} \\
\mathrm{F}\end{array}$ & & & $\begin{array}{l}\mathrm{F} \\
\mathrm{F} \\
\mathrm{F} \\
\mathrm{C} \\
\mathrm{F} \\
\mathrm{F}\end{array}$ & $\begin{array}{l}\mathrm{F} \\
\mathrm{F} \\
\mathrm{F} \\
\mathrm{F} \\
\mathrm{F}\end{array}$ \\
\hline
\end{tabular}


Table 8. (Continued).

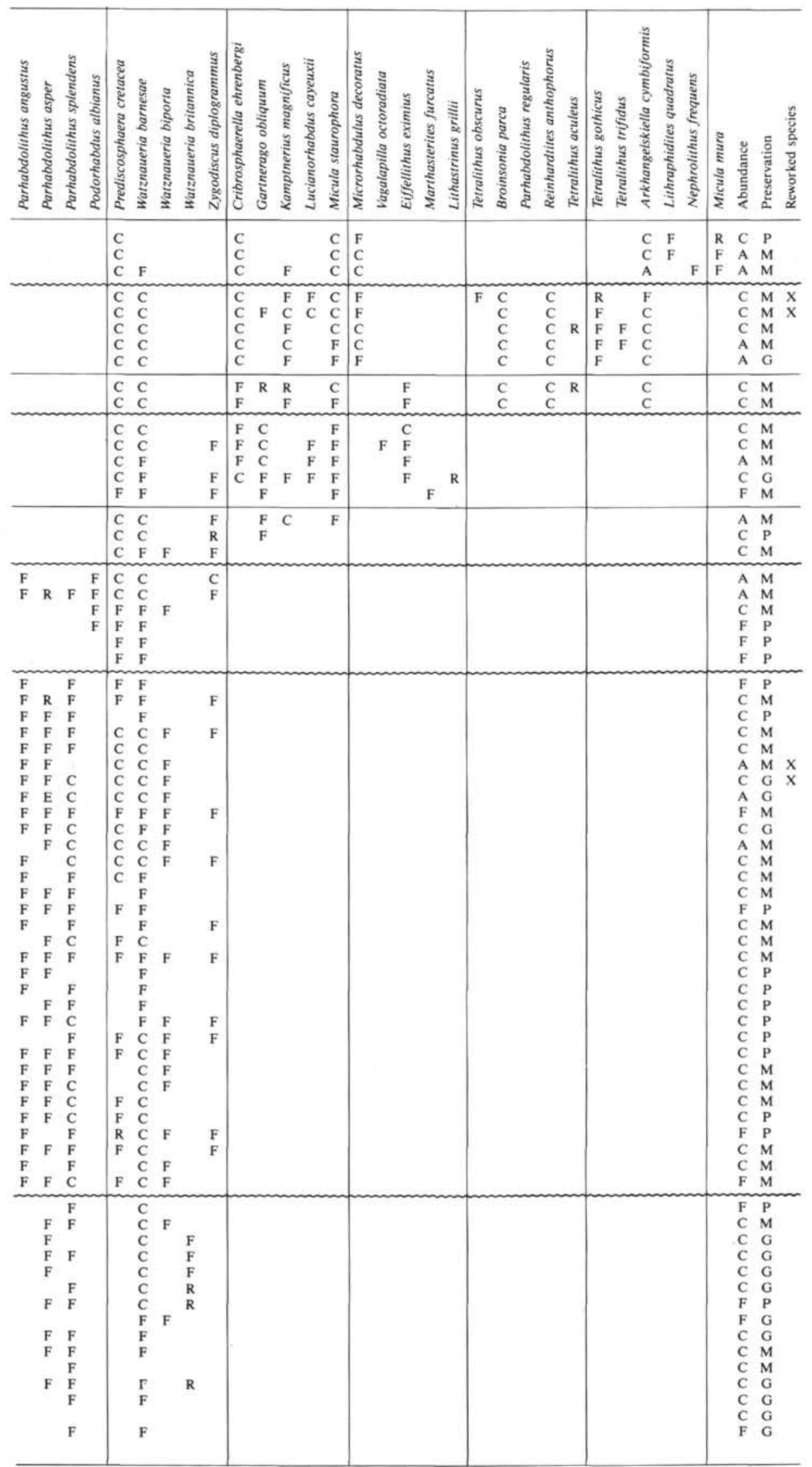


Table 9. Distribution of calcareous nannofossils in Miocene to Pleistocene sediments, Hole 550. Symbols and abbreviations as in Table 5. Double line between Cores 1 and 2 corresponds to a $94 \mathrm{~m}$ gap in the coring.

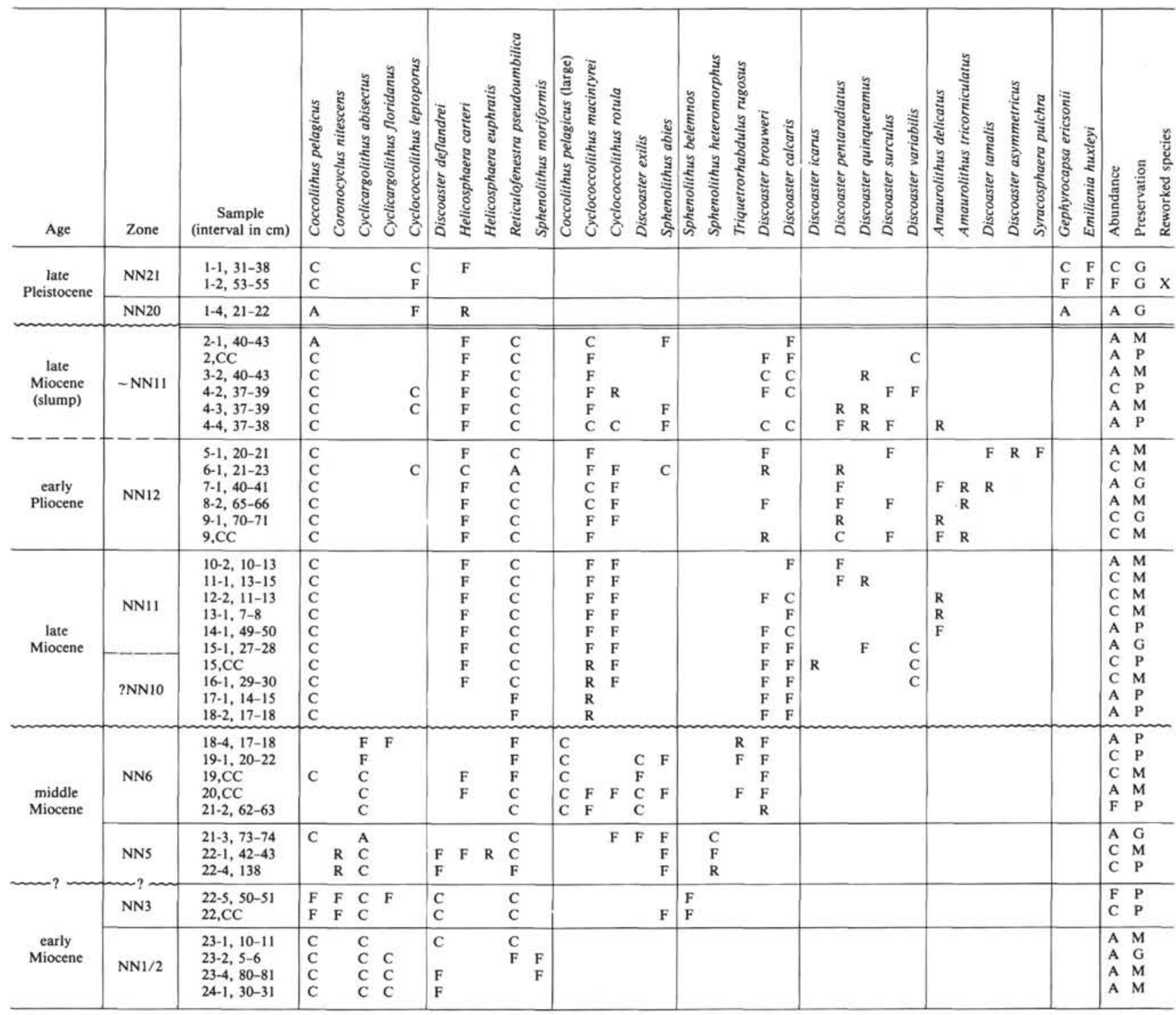

400 (Leg 48), and an unconformity is present at Sites 403 and 406 on the flank of Rockall Bank. These events correspond to a major global unconformity about 29 m.y. old (boundary NP23/NP24), described by Vail and Hardenbol (1979). This important oceanographic change around the NP23/NP24 boundary may have been a response to plate movements.

The Oligocene nannoplankton assemblages are characterized by lower diversity and the dominance of coolwater species of Reticulofenestra and Chiasmolithus. The presence of warm-water species like Sphenolithus distentus and Sphenolithus ciperoensis during middle and late Oligocene time (NP24-NP25) in the northeastern Atlantic indicates that a warm-water surface current, comparable to the Recent North Atlantic current, penetrated into the northeastern Atlantic and the Norwegian-Greenland Sea. During Leg 38 (Müller, 1976), nannoplankton assemblages comparable to those described from the North Atlantic were recovered on the flanks of the Iceland-Faeroe Ridge (Sites 336 and 352) and on the Vøring Plateau (Site 338) in a nannofossil ooze. This middle to late Oligocene age is the only interval during which nannofossil ooze was deposited in this area. This time interval corresponds to a high sea-level stand which caused a transgression connected with a facies change in the northwest European epicontinental basins.

Changing distribution of water masses caused by climatic fluctuations during deposition of nannoplankton Zone NP24 are inferred from the presence or absence of Chiasmolithus altus (Site 549) and from fluctuating abundances of Zygrhablithus bijugatus. Chiasmolithus altus is typical of the higher latitudes in the North Atlantic, and has not been reported found in tropical or subtropical regions. At Site 549 this species seems to be restricted to Zone NP24. For the same stratigraphic interval, Diester-Haass and Chamley (1980) described numerous eustatic sea-level changes indicated by results from Site 369 off northwest Africa. Alternating periods of arid 
and humid climate during this time are also indicated by palynological studies. More arid conditions developed within the late Oligocene (Sittler and Schuler, 1974).

The Oligocene/Miocene boundary is defined by the extinction of Dictyococcites dictyodus, Zygrhablithus bijugatus, Ericsonia fenestrata, Helicosphaera recta, and Sphenolithus ciperoensis (Müller, 1981). At this boundary, there is a remarkable upward decrease in size of the nannoplankton, and the diversity of the assemblages becomes very low. The presence of Discoaster deflandrei within Oligocene and lower Miocene sediments in high southern and northern latitudes indicates that this species is oligothermal, and cannot be used as an indicator of warm water.

\section{Miocene}

A drop in water temperature at the beginning of the Miocene is inferred from isotope analyses (RabussierLointier, 1980), and presumably was linked to oceanographic and climatic changes. Often at the Oligocene/ Miocene boundary an unconformity can be observed at which the lowermost Miocene is absent, as at Site 549. This hiatus is well known from many land sections, and is linked to a drop of sea level during earliest Miocene time. In epicontinental basins, the Oligocene/Miocene boundary often coincides with a lithofacies change.

Siliceous microfossils are lacking in most lower Miocene sediments recovered during Leg 80 . Only at Site 550 were fine laminated diatomites with very large diatoms deposited within nannoplankton Zone NN1. A comparable layer of the same age was observed at Site 440 (Leg 48).

The lower Miocene to lower middle Miocene sections (nannoplankton Zones NN2-NN5) are represented by very condensed sequences. This may be linked to a high sea-level stand during the time of deposition, and to the trapping of sediments on the shelf. The presence of tropical to subtropical species such as Sphenolithus belemnos and Sphenolithus heteromorphus in higher latitudes indicates increasing water temperature (from 22 to 15 m.y. ago) and northward penetration of warm water masses. This warming coincided with a rise of sea level and an important transgression that reached its maximum during the time corresponding to nannoplankton Zone NN5. The record of this transgression has been observed worldwide. It is recognized in the northwest European marginal basins, and is known in North Germany as the Hemmorian transgression. In this interval, warm-water species make it possible to determine nannoplankton Zones NN3 to NN5 in North Germany (Müller et al., 1979). Also, in many areas of the Mediterranean region, Burdigalian-Langhian (NN2-NN5) rocks are transgressive deposits.

Nannofossils are abundant in the lower Miocene sediments. Slight signs of dissolution occur in several layers at Site 550, but fragmentation of the fossils is mainly a diagenetic effect. Dissolution became stronger during deposition of nannoplankton Zone NN6 (middle Miocene), suggesting a rise of the CCD. This may have been related to oceanographic changes associated with decreasing water temperature, which started about 14 m.y. ago and reached a minimum about 11 to $12 \mathrm{~m}$.y. ago (Bizon and Müller, 1977). This cooling probably was caused by the growth of Antarctic ice masses. At the same time, the final closure of the Mediterranean seaway to the east took place (Meulenkamp, 1975; Bizon and Müller, 1977).

Large parts of the middle Miocene sequence have been eroded or were not deposited at Leg 80 drill sites. This hiatus (5.0 m.y.) represents an interval from the middle Miocene (upper NN6) to the upper Miocene (NN11). It may be associated with vigorous bottom circulation that developed after the exchange of water between the Norwegian Sea and the North Atlantic. The full exchange of water across the Iceland-Faeroe Ridge is inferred from post-middle Miocene subsidence criteria (Thiede, 1979). Sedimentation started again within nannoplankton Zone NN11. However, the middle Miocene hiatus at issue seems to be a worldwide phenomenon (Keller and Barron, 1983) related to the Antarctic glaciation and the global climatic deterioration that provoked stronger bottom-current activity.

The upper Miocene section is characterized by high accumulation rates, which can be attributed at least partially to interbedding of turbidites. Climatic fluctuations during deposition of the upper part of nannoplankton Zone NN11 are shown by fluctuations in the abundance of discoasters (Bizon and Müller, 1977; Müller, 1979a). Climatic oscillations during late Miocene time in the North Atlantic are also reported by Poore (1981). Layers with common discoasters alternate with layers in which discoasters are rare or lacking. The occurrence of Amaurolithus delicatus fluctuates in a similar pattern. Discoaster quinqueramus, a typical warm-water species, is less tolerant to decreasing water temperature than are Discoaster calcaris and Discoaster variabilis (Müller, 1979a). Thus, the two latter species are sometimes common in layers without Discoaster quinqueramus. Because of the scarcity of $D$. quinqueramus, determination of nannoplankton Zone NN11 is not always certain. Upper Miocene sediments are rich in nannoplankton, and often contain a large number of small coccoliths. This indicates high productivity, which is also suggested by the presence of siliceous microfossils.

At Site 550, white nannofossil ooze alternates with light gray clayey ooze (Hole 550, Cores 15-18) within the upper Miocene sequence. Dissolution and fragmentation of the nannofossils are stronger in the gray layers. The abundance of more dissolution-resistant discoasters increases, whereas coccolith have been almost destroyed. The discoasters are well preserved, without calcite overgrowths, owing to the high clay content. The cool-water species Discoaster variabilis is common. Fluctuations of the CCD are probably the main reason for these cycles, related to climatic changes and oscillations of water masses. Those cycles are also described, on the basis of samples from Neogene and older sediments, by Dean et al. $(1977,1981)$. Bolboforma specimens are common in several layers of the upper Miocene sequence (Müller et al., this vol.); they seem to prefer cool water.

\section{Pliocene}

The earliest Pliocene was characterized by warming surface waters, as shown by the larger number of warmwater species in the lowermost Pliocene. Within nanno- 
Table 10. Distribution of calcareous nannofossils in Paleogene sediments, Hole 550. Symbols and abbreviations as in Table 2.

\begin{tabular}{|c|c|c|c|c|c|c|c|c|c|c|c|c|c|c|c|c|c|c|c|}
\hline Age & Zone & $\begin{array}{c}\text { Sample } \\
\text { (interval in } \mathrm{cm} \text { ) }\end{array}$ & 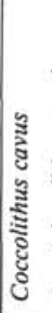 & 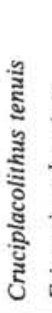 & 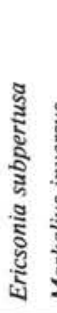 & 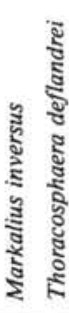 & 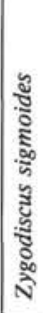 & 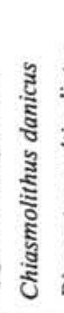 & 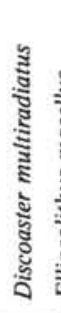 & 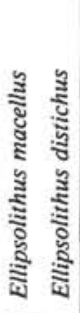 & 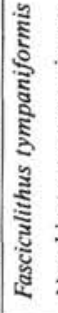 & 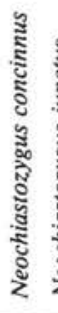 & 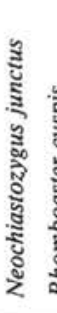 & 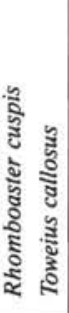 & 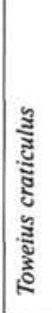 & 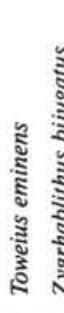 & 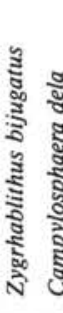 & 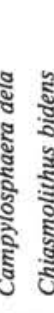 & 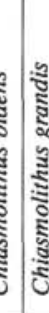 \\
\hline $\begin{array}{c}\text { late/ } \\
\text { middle } \\
\text { Oligocene }\end{array}$ & NP24/25 & $\begin{array}{l}24-1,45-46 \\
24-1,70-71 \\
24-1,130-131\end{array}$ & & & & & & & & & & & & & & & & & \\
\hline $\begin{array}{c}\text { early } \\
\text { Oligocene }\end{array}$ & NP21 & $\begin{array}{l}24-2,14-15 \\
24-2,34-35\end{array}$ & & & & & & & & & & & & & & & & & \\
\hline$?$ & NP20-17 & $24-2,62-63$ & & & & & & & & & & & & & & & & & \\
\hline $\begin{array}{l}\text { middle } \\
\text { Eocene }\end{array}$ & NP14 & $\begin{array}{l}24-2,95-96 \\
24-4,67-68\end{array}$ & & & & & & & & & & & & & & & & & r \\
\hline \multirow{4}{*}{$\begin{array}{l}\text { early } \\
\text { Eocene }\end{array}$} & NP13 & $\begin{array}{l}24-5,45-46 \\
24, C C \\
25-1,75-76 \\
25-3,97-99\end{array}$ & & & & $\mathbf{R}$ & & & & & & & & $\begin{array}{l}\text { cf. } \\
\text { cf. }\end{array}$ & & & & & I \\
\hline & NP12 & $\begin{array}{l}25-5,23-24 \\
26-1,39-40 \\
26, C C \\
27-2,38-39 \\
27-4,38-39 \\
27-6,29-30 \\
27, C C\end{array}$ & & & & $\begin{array}{l}\mathrm{R} \\
\mathrm{F}\end{array}$ & & & & $\begin{array}{l}R \\
R\end{array}$ & & & & \begin{tabular}{l|l} 
cf. & \\
cf. & \\
A & \\
A \\
A \\
A
\end{tabular} & & & & $\begin{array}{ll}\mathrm{F} & \\
\mathrm{R} & \\
& \mathrm{F}\end{array}$ & $F$ \\
\hline & NP11 & $\begin{array}{l}28-1,46-47 \\
28-3,46-47 \\
28-5,46-47 \\
28, C C \\
29-2,47-48 \\
29-5,74-75 \\
29, C C\end{array}$ & & & & $\begin{array}{l}\mathrm{F} \\
\mathrm{R} \\
\mathrm{R} \\
\mathrm{F} \\
\mathrm{F}\end{array}$ & & & & $\begin{array}{l}\mathrm{R} \\
\mathrm{R} \\
\mathrm{R} \\
\mathrm{R} \\
\mathrm{F} \\
\mathrm{F} \\
\mathrm{C}\end{array}$ & & & & \begin{tabular}{l|l} 
A & \\
C & \\
A & \\
A & \\
A & \\
A & \\
A &
\end{tabular} & & & F & $\begin{array}{l}F \\
F\end{array}$ & F \\
\hline & NP10 & $\begin{array}{l}30-1,46-47 \\
30-4,46-47 \\
30, C C \\
31-1,50-51 \\
31-4,50-51 \\
32-3,68-69 \\
32-6,68-69 \\
33-2,57-58 \\
33-5,56-58 \\
34-2,60-61 \\
34-3,60-61\end{array}$ & & & & $\begin{array}{l}\text { F } \\
\text { F } \\
\text { F } \\
\text { F }\end{array}$ & & & $\begin{array}{ll} & \mathrm{F} \\
\mathrm{F} & \mathrm{F} \\
\mathrm{F} & \mathrm{F} \\
\mathrm{F} & \mathrm{F} \\
\mathrm{F} & \\
\mathrm{C} & \\
\mathrm{C} & \\
\mathrm{C} & \\
\mathrm{C} & \\
\mathrm{C} & \end{array}$ & $\begin{array}{ll}\mathrm{F} & \mathrm{F} \\
\mathrm{R} & \\
\mathrm{R} & \\
\mathrm{R} & \\
\mathrm{F} & \\
& \mathrm{F} \\
& \mathrm{F} \\
\mathrm{R} & \mathrm{F} \\
& \mathrm{F}\end{array}$ & & & $\begin{array}{ll}\mathrm{F} \\
\mathrm{R} \\
\\
\\
\mathrm{F} \\
\mathrm{F} \\
\mathrm{F} \\
\\
\mathrm{F} & \\
\mathrm{F} & \mathrm{F} \\
& \mathrm{F}\end{array}$ & $\begin{array}{ll} & \mathrm{A} \\
\mathrm{A} \\
\mathrm{A} \\
\mathrm{A} \\
\mathrm{A} \\
\mathrm{A} \\
\mathrm{A} \\
\\
\mathrm{F} & \\
\mathrm{F} & \end{array}$ & $\begin{array}{l}\text { C } \\
\text { C } \\
\text { C } \\
\text { C } \\
\text { F } \\
\text { A } \\
\text { C } \\
\text { C }\end{array}$ & $\begin{array}{lll} & & \\
\mathrm{R} & & \\
\mathrm{C} & \mathrm{F} & \\
\mathrm{C} & \\
\mathrm{R} & \\
\mathrm{C} & \\
\mathrm{C} & & \end{array}$ & $\begin{array}{ll} & \mathrm{F} \\
& \mathrm{F} \\
\mathrm{R} & \mathrm{R} \\
& \mathrm{R} \\
& \\
\mathrm{R} & \\
& \mathrm{F}\end{array}$ & $\begin{array}{ll}\mathrm{F} & \mathrm{F} \\
\mathrm{F} & \mathrm{F} \\
\mathrm{R} & \mathrm{F} \\
\mathrm{R} & \\
& \\
& \mathrm{F} \\
& \mathrm{R} \\
\mathrm{F} & \mathrm{F} \\
& \mathrm{F}\end{array}$ & \\
\hline \multirow{3}{*}{$\begin{array}{c}\text { late } \\
\text { Paleocene }\end{array}$} & NP9 & $\begin{array}{l}34-4,60-61 \\
34, \mathrm{CC} \\
35-3,30-31 \\
35-4,120-121 \\
36-1,36-37 \\
36-2,84-85\end{array}$ & & $\mathrm{~F}$ & & $\begin{array}{l}\text { F } \\
\text { R }\end{array}$ & & & $\begin{array}{ll}\mathrm{C} & \mathrm{F} \\
\mathrm{C} & \\
\mathrm{F} & \\
\mathrm{F} & \\
\mathrm{F} & \mathrm{F} \\
\mathrm{F} & \end{array}$ & \begin{tabular}{ll|} 
F & $F$ \\
& $F$ \\
& \\
& \\
&
\end{tabular} & $\begin{array}{l}\mathrm{F} \\
\mathrm{F} \\
\mathrm{C} \\
\mathrm{F} \\
\mathrm{F} \\
\mathrm{C}\end{array}$ & I & F F & & & $\begin{array}{l}\mathrm{C} \\
\mathrm{C} \\
\mathrm{C} \\
\mathrm{C}\end{array}$ & & F & \\
\hline & NP5 & $\begin{array}{l}36-3,7-8 \\
36-3,104-106\end{array}$ & $\mathrm{~F}$ & $\mathrm{~F}$ & $\begin{array}{l}\mathrm{F} \\
\mathrm{C}\end{array}$ & R $R$ & F & $\begin{array}{l}\mathrm{F} \\
\mathrm{A}\end{array}$ & & & $\mathrm{F}$ & F & & & $\begin{array}{l}\mathrm{F} \\
\mathrm{R}\end{array}$ & & & & \\
\hline & NP4 & $\begin{array}{l}36-4,1-2 \\
37-2,57-59 \\
37, C C \\
38-3,50-52 \\
38-5,50-52\end{array}$ & & $\begin{array}{l}\mathrm{F} \\
\mathrm{F} \\
\mathrm{F}\end{array}$ & $\begin{array}{l}\mathrm{F} \\
\mathrm{F} \\
\mathrm{F} \\
\mathrm{F}\end{array}$ & $\begin{array}{l}\text { F } \\
\text { C } \\
\text { F }\end{array}$ & $\begin{array}{l}\text { C } \\
\text { C } \\
\text { F } \\
\text { F } \\
\text { F }\end{array}$ & $\begin{array}{l}\text { A } \\
\text { A } \\
\text { C } \\
\text { F } \\
\text { F }\end{array}$ & $\begin{array}{ll}\mathrm{F} \\
\mathrm{F}\end{array}$ & $\begin{array}{l}R \\
R \\
R \\
F \\
F\end{array}$ & & $\begin{array}{l}\mathrm{F} \\
\mathrm{R}\end{array}$ & & & $\begin{array}{l}\mathrm{R} \\
\\
\mathrm{P} \\
\mathrm{R}\end{array}$ & & & & \\
\hline $\begin{array}{c}\text { early } \\
\text { Paleocene }\end{array}$ & NP3 & $\begin{array}{l}38-6,50-52 \\
39-2,24-27 \\
39-5,56-57 \\
40-1,5-8 \\
41-2,116-117\end{array}$ & & $\begin{array}{l}F \\
F \\
F \\
F \\
F\end{array}$ & $\begin{array}{l}F \\
F \\
F \\
F \\
F \\
F\end{array}$ & $\begin{array}{l}\mathbf{R} \\
\mathbf{R}\end{array}$ & $\begin{array}{l}\text { C } \\
\text { C } \\
\text { C } \\
\text { F } \\
\text { F }\end{array}$ & $\begin{array}{l}\mathrm{F} \\
\mathrm{F} \\
\mathrm{F}\end{array}$ & & & & & & & & & & & \\
\hline
\end{tabular}


Table 10. (Continued).

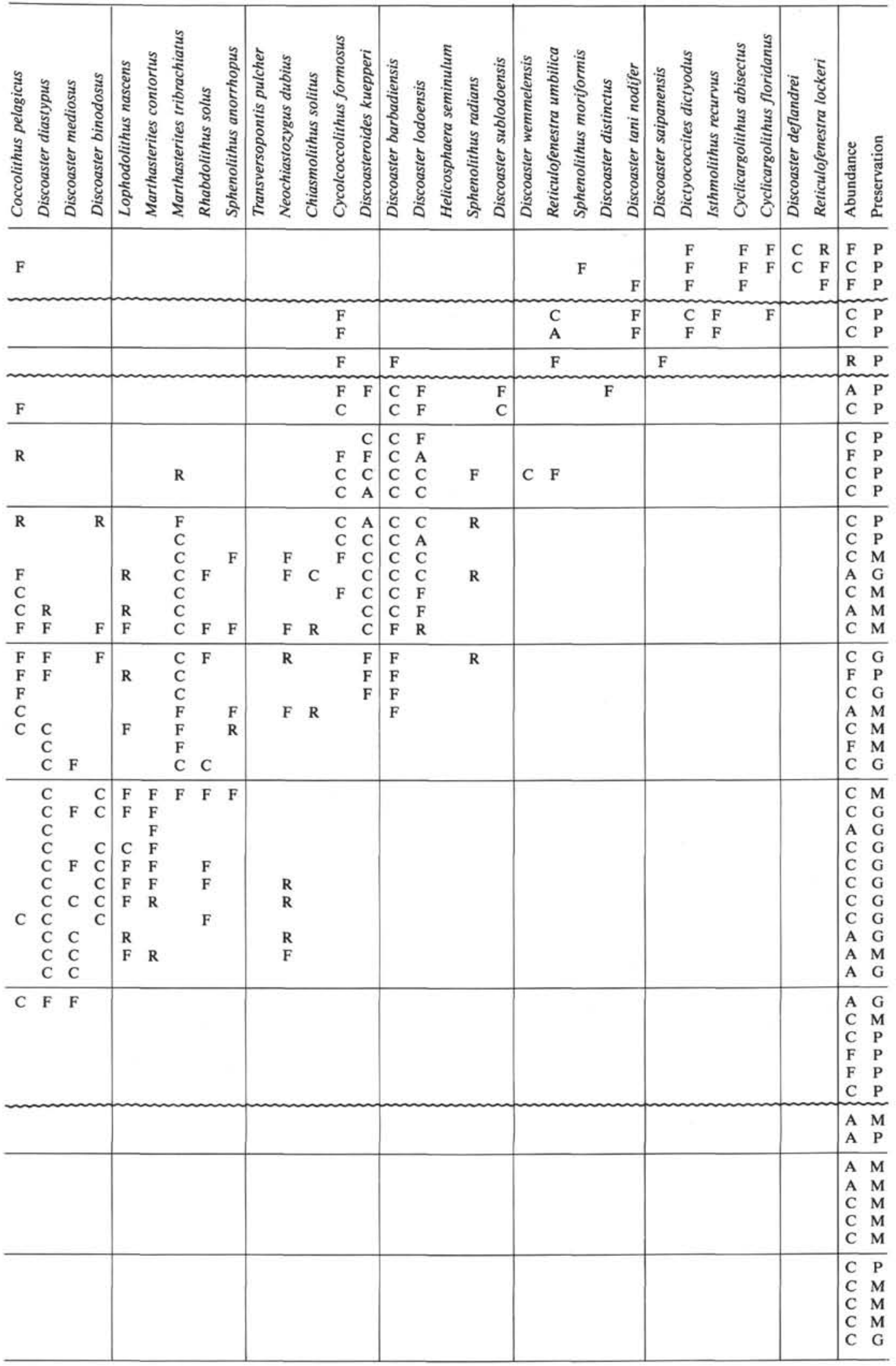




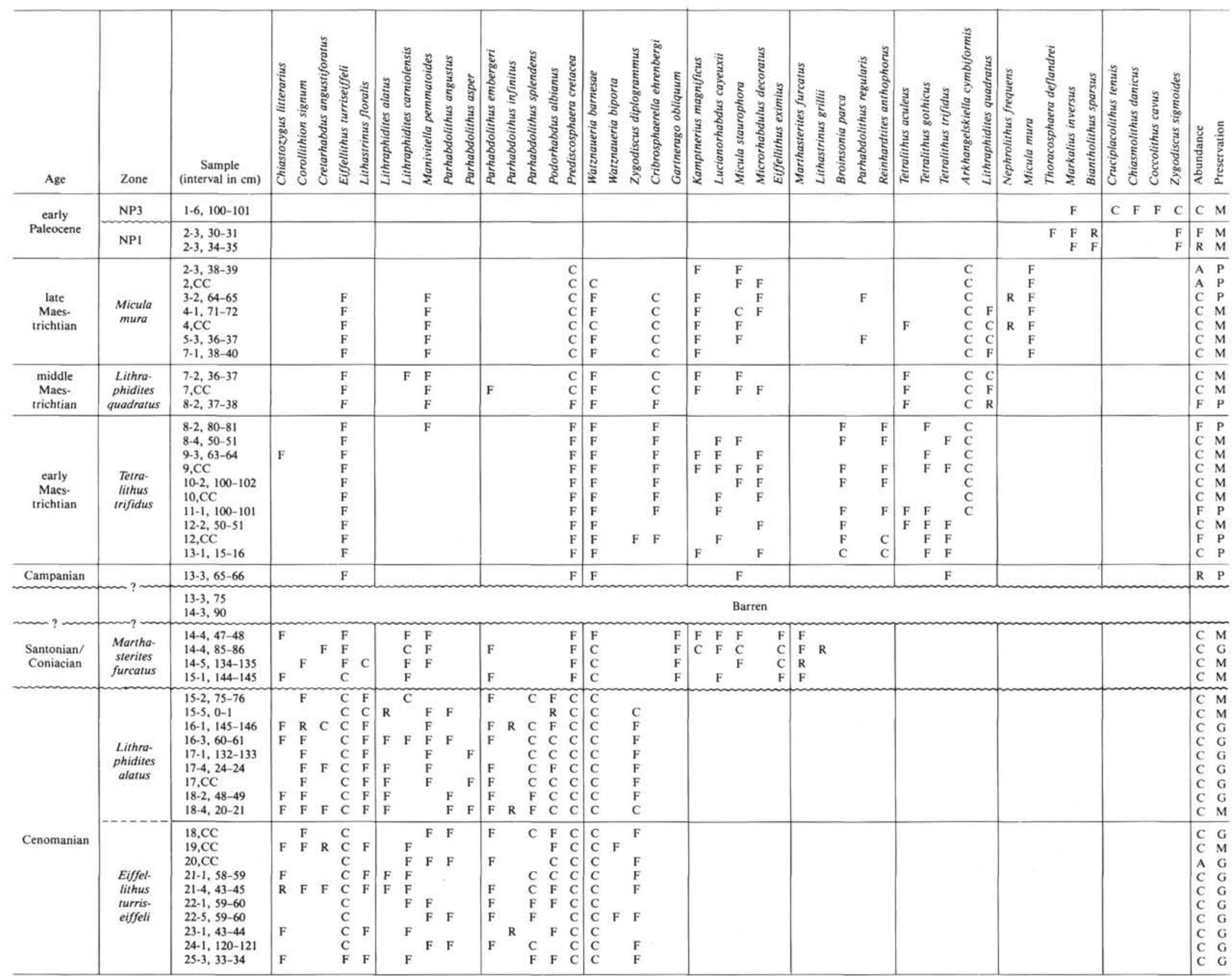


Table 12. Distribution of calcareous nannofossils in Cretaceous sediments, Hole 551. Symbols and abbreviations as in Table 2.

\begin{tabular}{|c|c|c|c|c|c|c|c|c|c|c|c|c|c|c|c|c|c|c|c|c|c|c|c|c|c|c|}
\hline Age & Zone & $\begin{array}{c}\text { Sample } \\
\text { (interval in } \mathrm{cm} \text { ) }\end{array}$ & 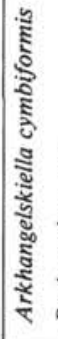 & 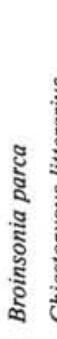 & 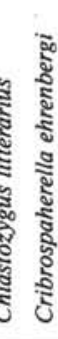 & 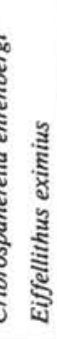 & 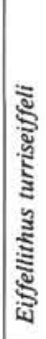 & 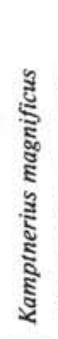 & 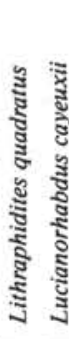 & 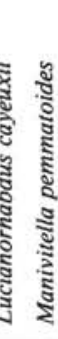 & 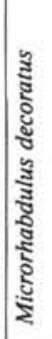 & 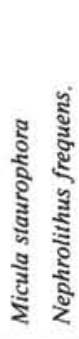 & 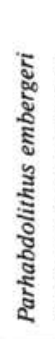 & 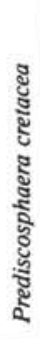 & 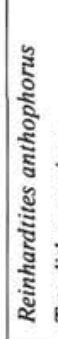 & 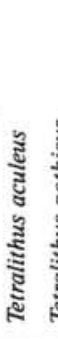 & 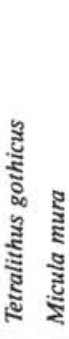 & 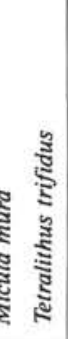 & 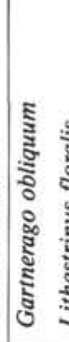 & 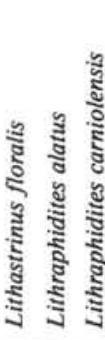 & 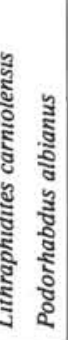 & 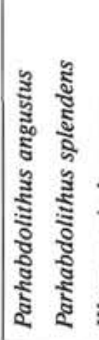 & 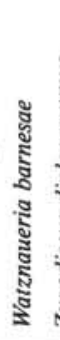 & 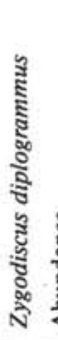 & 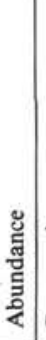 & \\
\hline $\begin{array}{c}\text { early } \\
\text { Maes- } \\
\text { trichtian }\end{array}$ & \multirow[t]{2}{*}{$\begin{array}{l}\text { Tetra- } \\
\text { lithus } \\
\text { trifidus }\end{array}$} & $\begin{array}{l}2-1,100-101 \\
2-2,100-101 \\
2-3,100-101 \\
2, \mathrm{CC} \\
3-1,70-71 \\
3-2,70-71 \\
3-3,70-71 \\
3, \mathrm{CC}\end{array}$ & $\begin{array}{l}\text { C } \\
\text { C } \\
\text { C } \\
\text { C } \\
\text { F } \\
\text { F } \\
\text { F }\end{array}$ & $\begin{array}{l}\text { C } \\
\text { F } \\
\text { F } \\
\text { C } \\
\\
\text { F } \\
\text { C }\end{array}$ & $\begin{array}{l}\text { C } \\
\text { C } \\
\text { C } \\
\text { C } \\
\text { A } \\
\text { C }\end{array}$ & c & $\begin{array}{l}\text { F } \\
\text { C } \\
\text { C } \\
\text { F } \\
\text { C } \\
\text { C } \\
\text { F } \\
\text { C }\end{array}$ & $\begin{array}{l}\text { F } \\
\text { F } \\
\text { F } \\
\text { C } \\
\text { C }\end{array}$ & $\begin{array}{l}\mathrm{R} \\
\mathrm{C} \\
\mathrm{F} \\
\mathrm{C} \\
\mathrm{A} \\
\mathrm{C} \\
\mathrm{F}\end{array}$ & $\begin{array}{ll} & \mathrm{F} \\
\mathrm{R} & \mathrm{F} \\
\mathrm{C} & \mathrm{F} \\
\mathrm{F} & \\
\mathrm{C} & \mathrm{F} \\
\mathrm{A} & \mathrm{F} \\
\mathrm{C} & \mathrm{C} \\
\mathrm{F} & \mathrm{F}\end{array}$ & $\begin{array}{l}\text { C } \\
\text { C } \\
\text { F } \\
\text { F } \\
\text { F } \\
\text { F } \\
\text { F } \\
\text { F }\end{array}$ & $\begin{array}{l}\mathrm{C} \\
\mathrm{F} \\
\mathrm{C}\end{array}$ & $\mathbf{R}$ & $\begin{array}{l}\mathrm{C} \\
\mathrm{C} \\
\mathrm{F} \\
\mathrm{C} \\
\mathrm{C}\end{array}$ & $\begin{array}{l}\text { C } \\
\text { C } \\
\text { C } \\
\text { C } \\
\\
\text { C }\end{array}$ & $\begin{array}{l:l}\mathbf{R} & \\
\mathbf{R} & \\
\mathbf{F} & \\
\mathbf{F} & 1 \\
\mathbf{R} & \end{array}$ & $\begin{array}{l}F \\
F \\
F \\
F \\
F \\
F \\
F \\
F\end{array}$ & $\begin{array}{l}\mathrm{R} \\
\mathrm{R} \\
\mathrm{F} \\
\mathrm{F} \\
\mathrm{F}\end{array}$ & \multicolumn{3}{|c|}{$\mathbf{R}$} & \multicolumn{3}{|r|}{ E } & \begin{tabular}{l|l} 
A & \\
A & \\
A & \\
A & A \\
A & \\
A & . \\
A &
\end{tabular} & $P$ \\
\hline $\begin{array}{c}\text { late } \\
\text { Campanian }\end{array}$ & & $\begin{array}{l}4-1,51-52 \\
4-2,41-42 \\
4-3,15-16 \\
4-4,40-41\end{array}$ & $\begin{array}{l}\mathrm{F} \\
\mathrm{F} \\
\mathrm{F} \\
\end{array}$ & $\begin{array}{l}\mathrm{C} \\
\mathrm{F} \\
\mathrm{C}\end{array}$ & $\begin{array}{l}\mathrm{C} \\
\mathrm{C} \\
\mathrm{A}\end{array}$ & $\begin{array}{l}F \\
F \\
F\end{array}$ & $\begin{array}{l}\text { C } \\
\text { C } \\
\text { C }\end{array}$ & $\begin{array}{l}F \\
F \\
\end{array}$ & $\mathrm{~F}$ & $\begin{array}{ll}F & F \\
& F \\
& F \\
F\end{array}$ & C & & C & $\begin{array}{l}\mathrm{C} \\
\mathrm{C} \\
\mathrm{C} \\
\mathrm{C}\end{array}$ & $\begin{array}{l}\mathrm{C} \\
\mathrm{C} \\
\mathrm{C}\end{array}$ & R & $\begin{array}{l}\text { C } \\
\text { F } \\
\text { F } \\
\text { F }\end{array}$ & & C & & $F$ & & $\begin{array}{l}\mathrm{C} \\
\mathrm{C} \\
\mathrm{C} \\
\mathrm{F}\end{array}$ & & \begin{tabular}{l|l}
$\mathbf{A}$ & \\
$\mathrm{A}$ & \\
$\mathrm{A}$ & \\
$\mathrm{A}$ &
\end{tabular} & $\begin{array}{l}\text { M } \\
P\end{array}$ \\
\hline $\begin{array}{c}\text { early } \\
\text { Turonian }\end{array}$ & & $\begin{array}{l}5-1,10-11 \\
5-1,30 \\
5-1,46 \\
5-1,80 \\
5-2,3-4 \\
5-2,70-71\end{array}$ & & 1 & $\begin{array}{l}F \\
F\end{array}$ & F & $\begin{array}{l}\mathrm{F} \\
\mathrm{F} \\
\mathrm{C}\end{array}$ & & 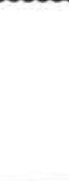 & $\begin{array}{l}\text { F } \\
\text { F } \\
\text { F }\end{array}$ & R & F & $\begin{array}{l}\mathrm{F} \\
\mathrm{R} \\
\mathrm{F} \\
\mathrm{F}\end{array}$ & $\begin{array}{l}\text { C } \\
\text { F } \\
\text { F } \\
\text { C } \\
\text { F } \\
\text { F }\end{array}$ & C & & & & $\begin{array}{ll} & \mathrm{F} \\
& \mathrm{F} \\
\mathrm{C} & \\
& \mathrm{F} \\
\mathrm{F} & \mathrm{R} \\
& \mathrm{F}\end{array}$ & $\begin{array}{l}\mathrm{F} \\
\mathrm{F} \\
\mathrm{F} \\
\mathrm{R} \\
\mathrm{R}\end{array}$ & $\mathbf{R}$ & R & $\begin{array}{l}\text { C } \\
F \\
F \\
C \\
C \\
F\end{array}$ & $\begin{array}{ll} \\
\mathrm{F}\end{array}$ & \begin{tabular}{l|l}
$\mathrm{C}$ & \\
$\mathrm{R}$ & \\
$\mathrm{C}$ & \\
$\mathrm{A}$ & \\
$\mathrm{A}$ & \\
$\mathrm{R}$ &
\end{tabular} & $\begin{array}{l}M \\
M\end{array}$ \\
\hline $\begin{array}{c}\text { late } \\
\text { Cenomanian }\end{array}$ & $\begin{array}{l}\text { Lithra- } \\
\text { phidites } \\
\text { alatus }\end{array}$ & $\begin{array}{l}6-1,40-41 \\
6-1,100-101 \\
6-3,91-92\end{array}$ & & 1 & $F$ & & $\begin{array}{l}\text { F } \\
\text { F } \\
\text { F }\end{array}$ & & & $\begin{array}{l}\mathrm{F} \\
\mathrm{F} \\
\mathrm{C}\end{array}$ & & & $\mathrm{F}$ & $\begin{array}{l}\mathrm{F} \\
\mathrm{C} \\
\mathrm{C}\end{array}$ & & & & & & $\begin{array}{ll}R & R \\
R & \\
F & R\end{array}$ & $\begin{array}{l}F \\
F \\
F\end{array}$ & F & $\begin{array}{l}\mathrm{C} \\
\mathrm{C}\end{array}$ & & $\begin{array}{l}\mathbf{A} \\
\mathbf{A} \\
\mathbf{A}\end{array}$ & P \\
\hline
\end{tabular}

plankton Zone NN12, discoasters and $A$. delicatus are more common. The preservation is good even at Site 550 , located on the abyssal plain. Discoaster pentaradiatus is generally of smaller size, as in tropical zones, and the bifurcations at the raytips are reduced or even missing.

Subdivision of the Pliocene section is imprecise because of the scarcity or absence of index fossils (ceratoliths, sphenoliths, discoasters), caused by low water temperature. Only a rough subdivision in the lower and upper Pliocene is possible, using the last occurrences of Reticulofenestra pseudoumbilica and Sphenolithus abies. The latter species is rare. Discoasters occur in a few samples up to the lowermost part of nannoplankton Zone NN16, but above that they are missing. The same distribution was observed in the western Mediterranean (Müller, 1978b). The disappearance of discoasters is correlated with the beginning of glaciation in the northern hemisphere about 2.7 to $2.5 \mathrm{~m}$.y. ago (Berggren, 1972; Bizon and Müller, 1977). It is also indicated by the occurrence of ice-rafted material and layers rich in reworked Cretaceous and Paleogene species. A short interval marked by strong dissolution was observed at Site 550 around the NN15/NN16 boundary.

The Plio/Pleistocene boundary is identified by the last occurrence of Cyclococcolithus macintyrei (Bizon and Müller, 1977, 1978), just below the top of the Olduvai event at about 1.7 m.y. (Hailwood et al., 1979; Snyder et al., this vol.). The disappearance of $C$. macintyrei corresponds to the extinction of Discoaster brouweri, and can be used for determining the Plio/Pleistocene boundary in areas where discoasters are missing or had an earlier disappearance.

\section{Pleistocene}

The Pleistocene sections recovered during Leg 80 are characterized by alternating nannoplankton-rich layers having more diversified assemblages and nannoplankton-poor layers having common reworked Cretaceous and Paleogene specimens and more detrital material. Within the latter intervals, autochthonous nannofossils are rare, and the assemblages consist of Emiliania huxleyi, Gephyrocapsa ericsonii, and few specimens of Coccolithus pelagicus. These layers were deposited during glacial periods when vast shelf areas were exposed to erosion. During the interglacial periods, nannoplankton-rich layers were deposited. Reworked species occur only rarely within these layers. The same phenomenon has been observed in the Pleistocene of the Norwegian-Greenland Sea (Müller, 1976), northwest of Africa (Müller and Rothe, 1975), and in the Mediterranean (Müller, 1979b). These alternations between layers rich and poor in nannoplankton are more pronounced within the upper Pleistocene (NN22-NN21) than in the lower Pleistocene (NN19). However, alternations are present throughout the Pleistocene at site 548, and also within the upper Pliocene. Signs of dissolution were observed only at Site 550 , which now lies at $4420 \mathrm{~m}$ water depth.

The Pleistocene nannoplankton assemblages of the northeastern Atlantic are dominated by Emiliania huxleyi, Gephyrocapsa ericsonii, and Coccolithus pelagicus. Other species, such as G. oceanica, Helicosphaera car- 
teri, Cycloccolithus leptoporus, Rhabdosphaera stylifera, and Syracosphaera pulchra, are few. Discolithina japonica and/or Pontosphaera pacifica are common within Zone NN19 and in the upper Pliocene. This was also observed in the material from Leg 48 (Müller, 1979a) and in material from certain areas of the Mediterranean (Müller, unpublished).

The uppermost part of nannoplankton Zone NN19 is characterized by an almost monospecific assemblage of a "small Gephyrocapsa." Pseudoemiliania lacunosa is rare. The "small Gephyrocapsa" horizon is known from other parts of the Atlantic and from the Mediterranean (Müller, in press). This level does not correspond, however, to a similar layer of "small Gephyrocapsa" (described by Gartner, 1980) in the Pacific (about 9 m.y. old), which corresponds to a period of rapid changes in ice volume.

\section{CONCLUSION}

The investigation of calcareous nannoplankton from the Cretaceous and Tertiary sections makes it possible to establish a detailed biostratigraphy for the sites (548-551) drilled during Leg 80 . It is possible to recognize unconformities and to correlate them with the "global" unconformities described by Vail and Hardenbol (1979), which are related to paleoceanographic events, eustatic sea-level changes, and/or tectonism. On the basis of nannoplankton assemblages and their preservation, curves of relative surface-water temperature and fluctuations of the CCD throughout the Tertiary at Goban Spur may be constructed.

\section{ACKNOWLEDGMENTS}

Thanks are due the Deutsche Forschungsgemeinschaft and the VW-Stiftung, which provided the Stereoscan Mark 2 to the Geologisch-Paläontologisches Institut, Universität Frankfurt am Main. My thanks also to Prof. Dr. E. Martini (Frankfurt am Main) for reviewing this paper.

\section{REFERENCES}

Berggren, W. A., 1972. Late Pliocene-Pleistocene glaciation. In Laughton, A. S., Berggren, W. A., et al., Init. Repts. DSDP, 12: Washington (U.S. Govt. Printing Office), 953-963.

Berggren, W. A., and Hollister, C., 1974. Paleogeography, paleobiogeography and the history of circulation of the Atlantic Ocean. In Hay, W. W. (Ed.), Studies in Oceanography: Spec. Publ. Soc. Econ. Paleontol. Mineral., 20:126-186.

Bizon, G., and Müller, C., 1977. Remarks on some biostratigraphic problems in the Mediterranean Neogene. Int. Symp. on the Structural History of the Mediterranean Basins: Paris (Technip), pp. 381-390.

, 1978. Remarks on the determination of the Plio/Pleistocene boundary in the Mediterranean. In Hsü, K. J., Montadert, L., et al., Init. Repts. DSDP, 42, Pt. 1: Washington (U.S. Govt. Printing Office), 847-854.

Buchardt, B., 1978. Oxygen isotope paleotemperature from the Tertiary period in the North Sea area. Nature, 275:121-123.

Bukry, D., and Bramlette, M. N., 1970. Coccoliths age determinations, Leg 3, Deep Sea Drilling Project. In Maxwell, A. E., Von Herzen, R. P., et al., Init. Repts. DSDP, 3: Washington (U.S. Govt. Printing Office), 589-611.

Cavelier, C., Châteauneuf, J. J., Pomerol, C., Rabussier, D., Renard, M., and Vergnaud Grazzini, C., 1981. The geological events at the Eocene/Oligocene boundary. Palaeogeogr. Palaeoclimatol. Palaeoecol., 36:223-248.
Čepek, P., and Hay, W. W., 1969. Calcareous nannoplankton and biostratigraphic subdivision of the Upper Cretaceous. Trans. Gulf Coast Assoc. Geol. Soc., 19:323-336.

Dean, W. E., Gardner, J. V., and Cepek, P., 1981. Tertiary carbonatedissolution cycles on the Sierra Leone Rise, eastern equatorial Atlantic Ocean. Mar. Geol., 39:81-101.

Dean, W. E., Gardner, J. V., Jansa, L. F., Čepek, P., and Seibold, E., 1977. Cyclic sedimentation along the continental margin of northwest Africa. In Lancelot, Y., Seibold, E., et al., Init. Repts. DSDP, 41: Washington (U.S. Govt. Printing Office), 965-986.

de Boer, P. L., and Wonders, A. A. H., 1981. Milankovitch parameters and bedding rhytmns in Umbrian middle Cretaceous pelagic sediments. IAS Second Eur. Mtg. (Bologna, 1981), pp. 10-13. (Abstract)

de Graciansky, P. C., Brosse, E., Deroo, G., Herbin, J. P., Montadert, L., Müller, C., Sigal, J., and Schaff, A., 1982. Les formations d'âge Crétacé de l'Atlantique Nord et leur matière organique: $\mathrm{Pa}$ léogéographie et milieux de dépôt. Rev. Inst. Fr. Pet., 37(3):105-166.

Diester-Haass, L., and Chamley, H., 1980. Oligocene climatic, tectonic and eustatic history off NW Africa (DSDP Leg 41, Site 369). Oceanol. Acta, 3(1):115-126.

Gartner, S., 1980. Paleoceanographic implication of the dominance of small Gephyrocapsa in the mid-Pleistocene nannoflora. 432 . (Abstract)

Hailwood, E. A., Bock, W., Costa, L., Dupeuble, P. A., Müller, C., and Schnitker, D., 1979. Chronology and biostratigraphy of northeast Atlantic sediments, DSDP Leg 48. In Montadert, L., Roberts, D. G., et al., Init. Repts. DSDP, 48: Washington (U.S. Govt. Printing Office), 1119-1141.

Hart, M. B., and Bigg, P. J., 1981. Anoxic events in the late Cretaceous chalk seas of North-West Europe. Internat. Geol. Correlat. Program, Project 58:177-185.

Keller, G., and Barron, J. A., 1983. Paleoceanographic implications of Miocene deep-sea hiatuses. Geol. Soc. Am. Bull., 94:590-613.

Kennett, J. P., 1977. Cenozoic evolution of Antarctic glaciation, the circum-Antarctic Ocean, and their impact on global paleoceanography. J. Geophys. Res., 82(27):3843-3860.

Martini, E., 1971. Standard Tertiary and Quaternary calcareous nannoplankton zonation. Proc. Second Planktonic Conf. (Rome, 1970), 2:739-785.

1976. Cretaceous to Recent calcareous nannoplankton from the central Pacific Ocean (DSDP Leg 33). In Schlanger, S. O., Jackson, E. D., et al., Init. Repts. DSDP, 33: Washington (U.S. Govt. Printing Office), 383-423.

Mélières, F., 1979. Mineralogy and geochemistry of selected Albian sediments from the Bay of Biscay, Deep Sea Drilling Project Leg 48. In Montadert, L., Roberts, D. G., et al., Init. Repts. DSDP, 48: Washington (U.S. Govt. Printing Office), 855-875.

Meulenkamp, J. E., 1975. Report of the Working Group on Micropaleontology. Report on Activity of the R.C.M.N.S. Working Groups (1971-1975): Bratislava, pp. 9-29.

Montadert, L., Roberts, D. G., De Charpal, O., and Guennoc, P., 1979. Rifting and subsidence of the northern continental margin of the Bay of Biscay. In Montadert, L., Roberts, D. G., et al., Init. Repts. DSDP, 48: Washington (U.S. Govt. Printing Office), 1025-1060.

Müller, C., 1976. Tertiary and Quaternary calcareous nannoplankton in the Norwegian-Greenland Sea, DSDP Leg 38. In Talwani, M., Udintsev, G., et al., Init. Repts. DSDP, 38: Washington (U.S. Govt. Printing Office), 823-841.

1978a. Remarks on biostratigraphic useful nannofossils in the Paleogene of the northern hemisphere. Newsl. Stratigr., 7(1): 45-52.

, 1978b. Neogene calcareous nannofossils from the Mediterranean-Leg 42A of the Deep Sea Drilling Project. In Hsü, K. J., Montadert, L., et al., Init. Repts. DSDP, 42, Pt 1: Washington (U.S. Govt. Printing Office), 727-752.

1979a. Calcareous nannoplankton from the North Atlantic (Leg 48). In Montadert, L., Roberts, D. G., et al., Init. Repts. $D S D P, 48$ : Washington (U.S. Govt. Printing Office), 589-639.

, 1979b. Les nannofossiles calcaires. In Burollet, P. F., Clairefond, P., and Winnock, E., (Eds.), La Mer Pélagienne. Geol. Mediter., VI(1):210-220. 
1981. Calcareous nannoplankton and silicoflagellates. In search of the Paleogene/Neogene boundary stratotype. Gior. Geol., 54:55-66.

, in press. Late Miocene to Recent biostratigraphic and paleoenvironmental results from the Mediterranean based on calcareous nannoplankton: Berlin (Springer-Verlag).

Müller, C., Kuster, H., Spiegler, D., and von Daniels, C. H., 1979. Nachweis von Nannoplankton-Zonen und ihre Korrelation mit lokalen stufen im Neogen NW-Deutschlands. Newsl. Stratigr., 8(2): 153-158.

Müller, C., and Rothe, P., 1975. Nannoplankton contents in regard to petrological properties of deep-sea sediments in the Canary and Cap Verde area. Mar. Geol., 19:259-273.

Perch-Nielsen, K., 1977. Albian to Pleistocene calcareous nannofossils from the western South Atlantic. In Supko, P. R., Perch-Nielsen, K., et al., Init. Repts. DSDP, 39: Washington (U.S. Govt. Printing Office), 699-825.

1979. Calcareous nannofossil zonation at the CretaceousTertiary boundary in Denmark. Symp. Cretaceous-Tertiary Boundary Events (Copenhagen, 1979), 1:115-135.

Poore, R., 1981. Late Miocene biogeography and paleoclimatology of the central North Atlantic. Mar. Micropaleontol., 6:599-616.

Rabussier-Lointier, D., 1980. Variations de composition isotopique de l'oxygène et du carbone en milieu marine et coupures stratigraphiques du Cenozoïque (thesis). University of Paris.

Shafik, S., 1981. Nannofossil biostratigraphy of the Hantkenina (foraminiferid) interval in the upper Eocene of southern Australia. BMR J. Austral. Geol. Geophys., 6:108-116.

Sittler, C., and Schuler, M., 1974. Rapports entre les fractions argileuses et les associations sporopolliniques des formations lacustres et palustres du bassin oligocène de Manosque. C.R. $96^{e}$ Congr. Nat. Soc. Sav. (Toulouse, 1971), II:31-45.

Thiede, J., 1979. History of the North Atlantic Ocean; evolution of an asymmetric zonal paleo-environment in a latitudinal ocean basin. In Talwani, M., Hay, W., and Ryan, W. B. F. (Eds.), Deep Sea Drilling Results in the Atlantic Ocean: Continental Margins and Paleoenvironments. Am. Geophys. Union, Maurice Ewing Ser. 3: 275-296.

Thierstein, H. R., 1973. Lower Cretaceous calcareous nannoplankton biostratigraphy. Abh. Geol. Bundesanst. (Austria), 29:1-52. 1976. Mesozoic calcareous nannoplankton biostratigraphy of marine sediments. Mar. Micropaleontol., 1:325-362.

Thierstein, H. R., and Okada, H., 1979. The Cretaceous/Tertiary boundary event in the North Atlantic. In Tucholke, B. E., Vogt, P. R., et al., Init. Repts. DSDP, 43: Washington (U.S. Govt. Printing Office), 601-616.

Vail, P. R., and Hardenbol, J., 1979. Sea-level change during the Tertiary. Oceanus, 22:71-79.

Vail, P. R., Mitchum, R. M., and Thompson, S., 1977. Global cycles of relative changes of sea level. Mem. Am. Assoc. Petrol. Geol., 26:83-98.

Vergnaud Grazzini, C., Müller, C., Pierre, C., Létolle, R., and Peypouquet, J. P., 1979. Stable isotopes and Tertiary paleontological paleoceanography in the Northeast Atlantic. In Montadert, L., Roberts, D. G., et al., Init. Repts. DSDP, 48: Washington (U.S. Govt. Printing Office), 475-491.

Date of Initial Receipt: September 23, 1982 Date of Acceptance: February 8, 1983 

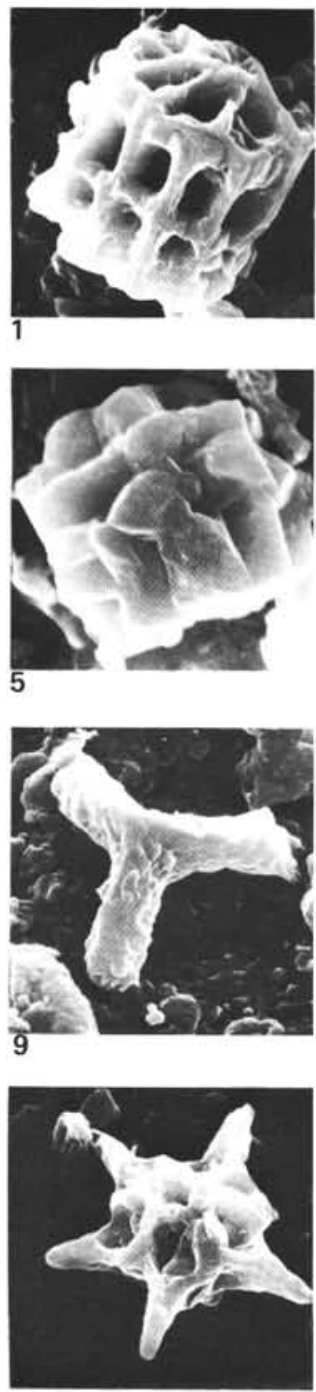

13

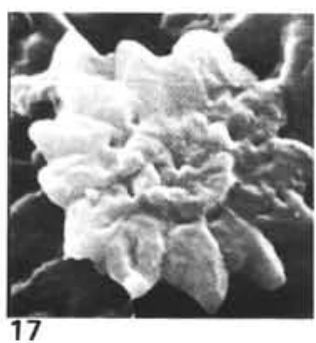

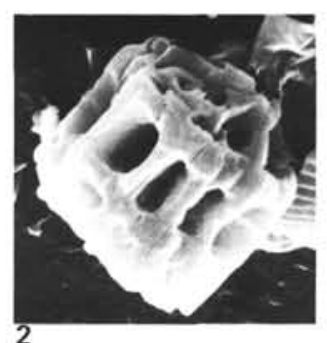
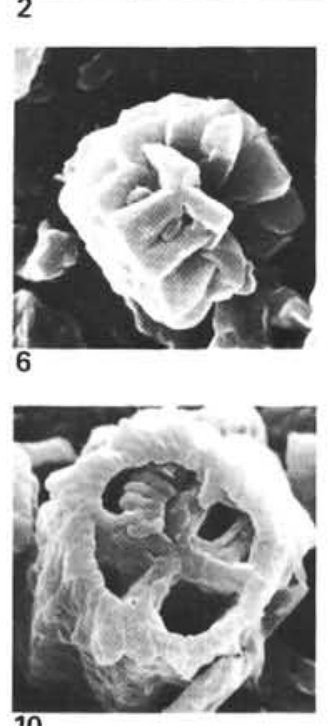

10

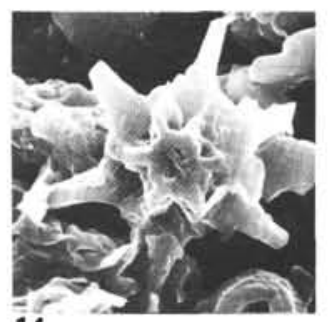

14

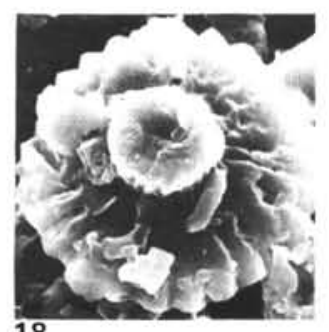

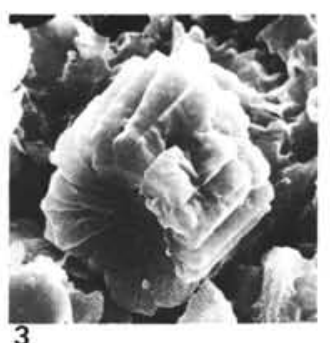
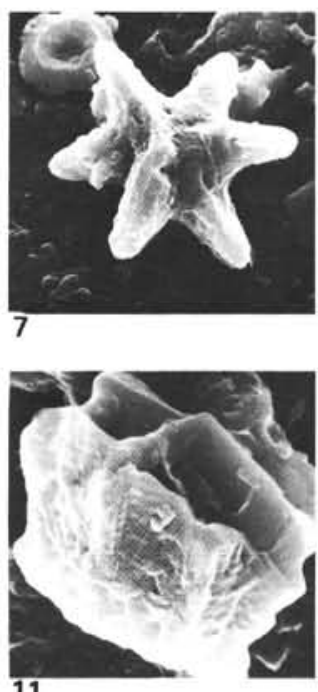

11

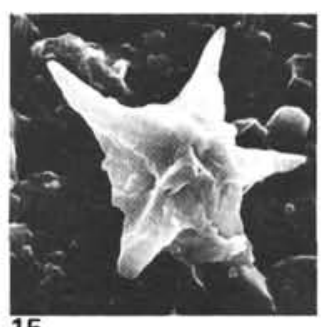

15

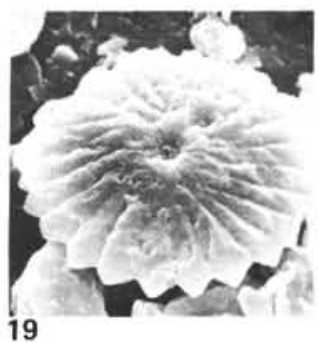

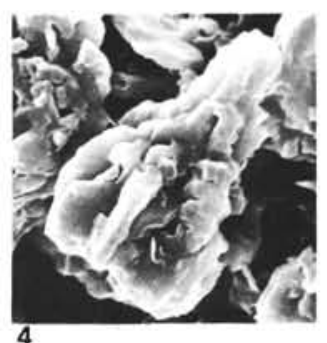

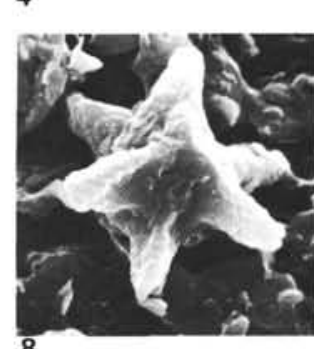

8

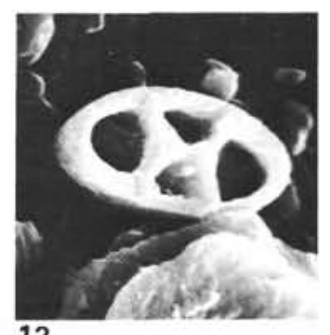

12
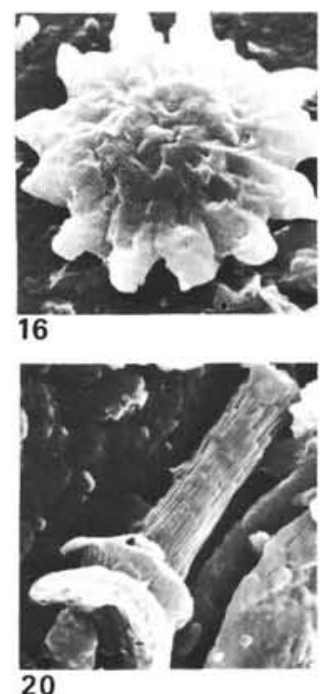

Plate 1. Paleogene calcareous nannoplankton. 1-2. Fasciculithus involutus Bramlette and Sullivan, 1961. Sample 550-36-1, 46-47 cm, upper Paleocene, Zone NP9. (1) $\times 4500$, side view, (2) $\times 3750$, side view. 3. Fasciculithus tympaniformis Hay and Mohler, 1967. Sample 549-18-2, 30-31 cm, upper Paleocene, Zone NP9, $\times 3500$, side view. 4. Fasciculithus lillianae Perch-Nielsen, 1971. Sample 549-17-1, 60-61 cm, upper Paleocene, Zone NP9, $\times 3500$, side view. 5-6. Sphenolithus primus Perch-Nielsen, 1971. Sample 549-18-2, 30-31 cm, upper Paleocene, Zone NP9. (1) $\times 7000$, side view, (2) $\times 5000$, side view. 7-8. Marthasterites contortus (Stradner) Deflandre, 1959. Sample 550-30-6, 46-47 cm, lower Eocene, Zone NP10, $\times 2750$, side views. 9. Marthasterites tribrachiatus (Bramlette and Riedel) Deflandre 1959. Sample 548A-23,CC, lower Eocene, Zone NP12, $\times 3500$, side view. 10-11. Chiphragmalithus barbatus Perch-Nielsen, 1967. Sample 550-27-6, 29-30 cm, lower Eocene, Zone NP12. (10) $\times 5000$, proximal view, (11) $\times 5000$, side view. 12. Neochiastozygus dubius (Deflandre) Black, 1967. Sample 550-33-5, 57-58 cm, lower Eocene, Zone NP10, $\times 5000$, side view. 13-15. Discoaster mahoudii Perch-Nielsen, 1981. Sample 550-34-2, 60-61 cm, lower Eocene, Zone NP10. (13-14) $\times 3500$, distal views, $(15) \times 3700$, proximal view. 16-17. Discoaster helianthus Bramlette and Sullivan, 1961. Sample 550-36-1, 46-47 cm, upper Paleocene, Zone NP9. (16) $\times 3500$, distal view, $(17) \times 3350$, proximal view. 18. Discoaster diastypus Bramlette and Sullivan, 1961. Sample 550-34-2, 60-61 cm, lower Eocene, Zone NP10, $\times 3500$, distal view. 19. Discoaster multiradiatus Bramlette and Riedel, 1954. Sample 550-31-3, 50-51 cm, lower Eocene, Zone NP10, $\times 3000$, proximal view. 20. Rhabdosphaera truncata Bramlette and Sullivan, 1961. Sample 548A-23,CC, lower Eocene, Zone NP12, $\times 5000$, side view. 

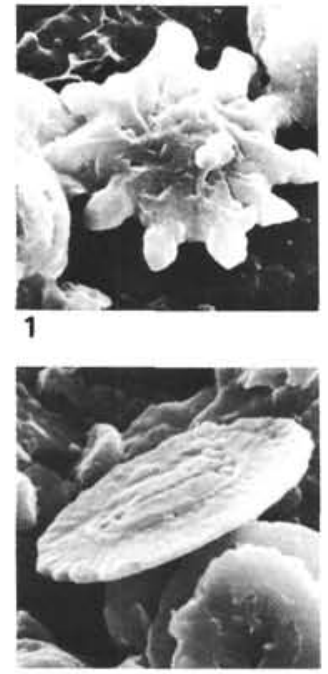

5

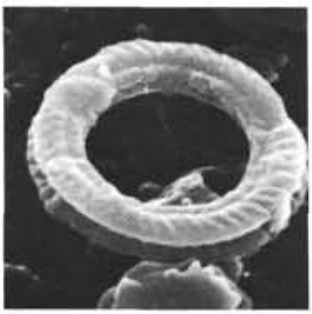

9

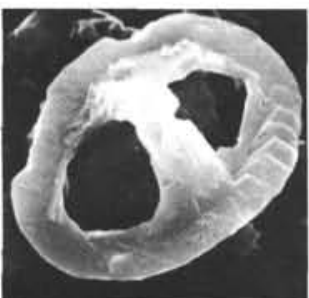

13

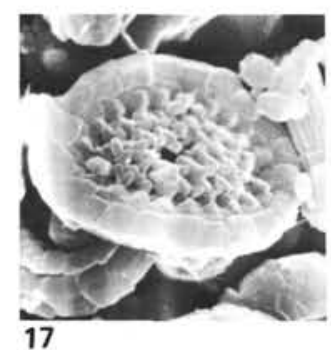

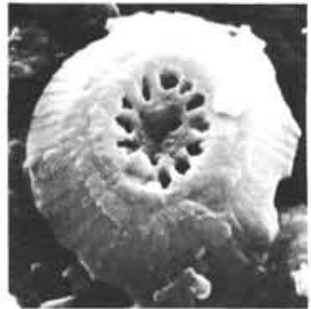

2

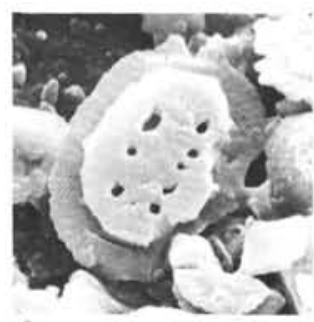

6

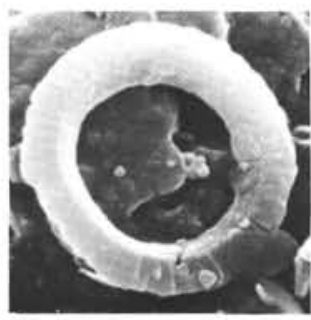

10

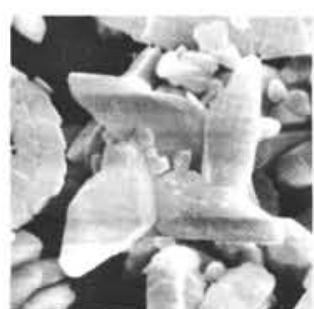

14

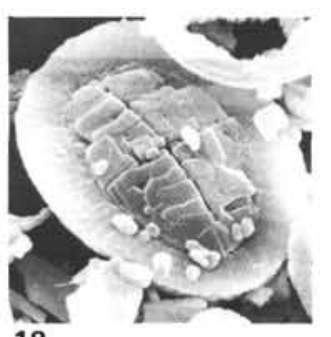

18

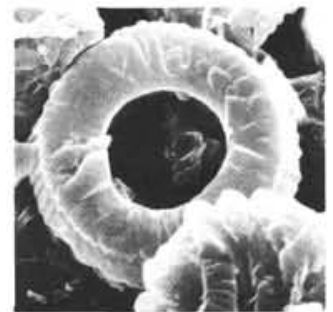

3

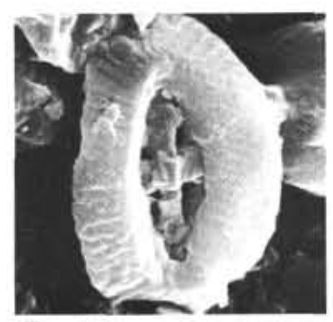

7

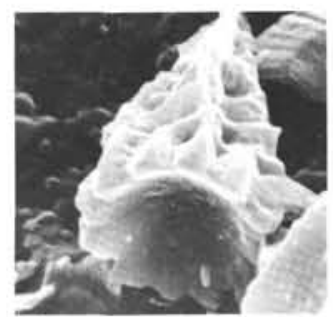

11

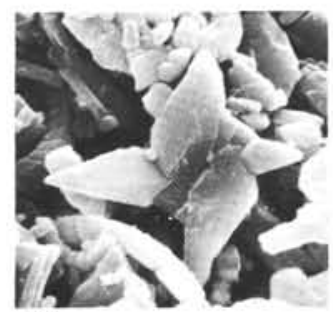

15

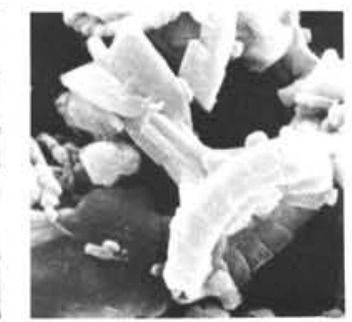

19

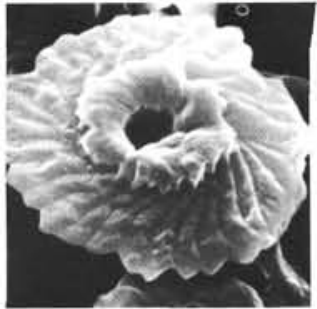

4

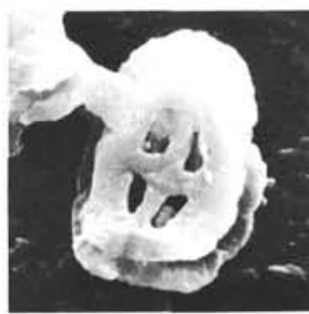

8

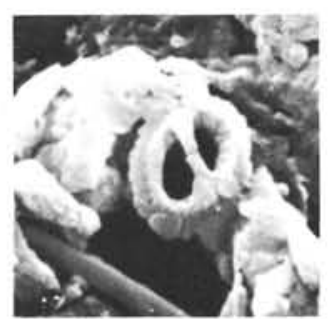

12

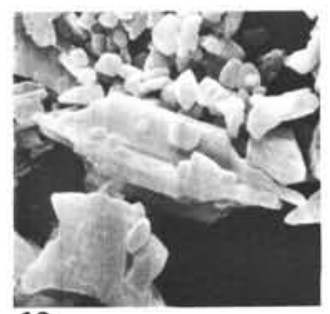

16

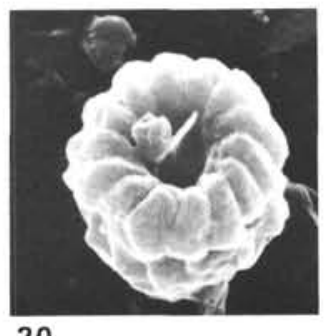

20

Plate 2. Calcareous nannoplankton. 1. Discoaster mediosus Bramlette and Sullivan, 1961. Sample 550-32-1, 68-69 cm, lower Eocene, Zone NP10, $\times 4000$, distal view. 2. Toweius carticulus Hay and Mohler, 1967. Sample 550-33-5, 57-68 cm, lower Eocene, Zone NP10, $\times 3000$, distal view. 3. Ericsonia subpertusa Hay and Mohler, 1967 . Sample 549-18-2, 30-31 cm, upper Paleocene, Zone NP9, $\times 3500$, distal view. 4. Cyclolithella aprica Roth, 1973. Sample 550-36-1, 46-47 cm, upper Paleocene, Zone NP9, $\times 6000$. 5-6. Ellipsolithus macellus (Bramlette and Sullivan) Sullivan, 1964. Sample 550-31-3, 50-51 cm, lower Eocene, Zone NP10. (5) $\times 4500$, distal view, (6) $\times 3500$, proximal view. 7-8. Campylosphaera dela (Bramlette and Sullivan) Hay and Mohler, 1967. Lower Eocene, Zone NP10. (7) Sample 550-30-6, 46-47 cm, $\times 5000$, distal view, (8) Sample 550-32-1, 18-19 cm, $\times 5000$, proximal view. 9. Cyclococcolithus sp., Sample 548A-23, CC, lower Eocene, Zone NP12. $\times 5000$, distal view. 10. Cycloccolithina protoannula Gartner, 1969. Sample 548A-23,CC, lower Eocene, Zone NP12, $\times 3500$, distal view. 11. Sphenolithus radians Deflandre, 1954. Sample 548A-23,CC, lower Eocene, Zone NP12, $\times 5000$, side view. 12. Gephyrocapsa aperta Kamptner, 1963. Sample 548-24,CC, lower Pliocene, Zone NN15, $\times 11,000$, distal view. 13. Zygodiscus sigmoides Bramlette and Sullivan, 1961. Sample 550-34-2, 60-61 $\mathrm{cm}$, lower Eocene, Zone NP10, $\times 5000$, distal view. 14-15. Micula mura (Martini) Bukry, 1973. Sample 458A-29-1, 1-2 cm, upper Maestrichtian. (14) $\times 6000$, (15) $\times 4500$. 16. Lithraphidites quadratus Bramlette and Martini, 1964. Sample 548A-29-1, 1-2 cm, upper Maestrichtian, $\times 3750$, side view. 17. Cribrosphaerella ehrenbergi Archangelsky, 1912. Sample 548A-29-1, 1-2 cm, Maestrichtian, $\times 5000$, distal view. 18 . Arkhangelskiella cymbiformis Vekshina, 1959. Sample 548A-29-1, 1-2 cm, Maestrichtian, $\times 5000$, distal view. 19. Prediscosphaera cretacea (Archangelsky) Gartner, 1968. Sample 548A-29-1, 1-2 cm, Maestrichtian, $\times$ 4500, side view. 20. ?Cribrocorona gallica (Stradner) Perch-Nielsen, 1973. Sample 548A-29-1, 1-2 cm, Maestrichtian, $\times 5500$, distal view. 